\title{
Tuning Cross-Coupling Approaches to C3 Modification of 3-Deazapurines
}

\author{
Łukasz J. Weseliński, ${ }^{\circledR}$ Vagarshak Begoyan, Alexis Ferrier, and Marina Tanasova*i] \\ Department of Chemistry, Michigan Technological University, 1400 Townsend Drive, Houghton, Michigan 49931, United States
}

Supporting Information

ABSTRACT: A general approach to C3 modification of purine scaffold through various types of cross-coupling reactions has been established. Tuning substrate electronics and reaction conditions resulted in the development of highly efficient $\mathrm{sp}^{2}-\mathrm{sp}, \mathrm{sp}^{2}-\mathrm{sp}^{2}$, and $\mathrm{sp}^{2}-\mathrm{sp}^{3}$ cross-coupling conditions for modification of 3-deazaadenine to access C3modified adenine and hypoxanthine scaffolds. The optimized methodologies to access the corresponding 3-deazaadenosine phosphoramidites for solid-phase DNA synthesis have been demonstrated.

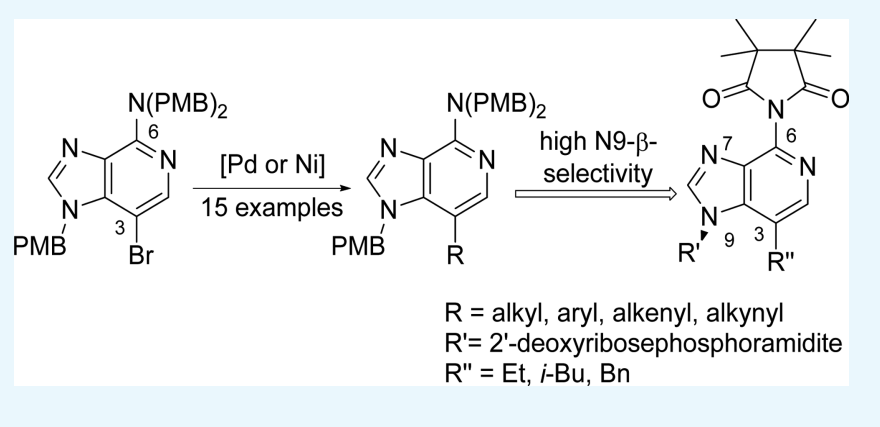

direct access to C-3 modified purine scaffolds would be therefore of interest. Here, we describe a general strategy that allows the deliberate synthesis of various 3-deaza-3-substituted purine analogues through metal-catalyzed cross-coupling reactions.

\section{RESULTS AND DISCUSSION}

En route to 3-deazaadenine analogues of purines, we first investigated the reactivity of the readily available 3-deazaadenine 1 (Scheme 1) in cross-coupling reactions. ${ }^{15}$ In direct attempts to utilize it as a cross-coupling partner, we were able

Scheme 1. Synthesis of Compounds 1-4
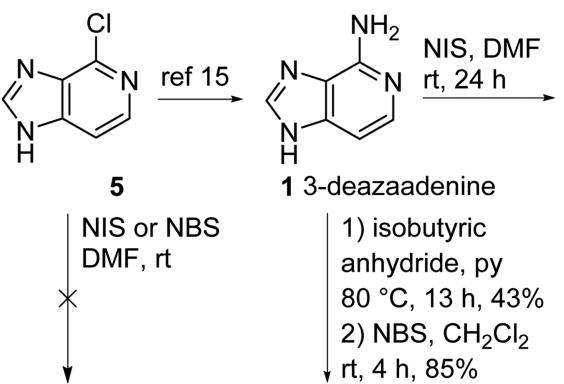

1) isobutyric anhydride, py $80{ }^{\circ} \mathrm{C}, 13 \mathrm{~h}, 43 \%$ 2) NBS, $\mathrm{CH}_{2} \mathrm{Cl}_{2}$ $\checkmark \mathrm{rt}, 4 \mathrm{~h}, 85 \%$ palladium-catalyzed methylations of 3-deaza-3-bromoadenosine analogues through Kumada coupling have been demonstrated. ${ }^{17,20}$ Recently, the modification of adenosine nucleosides through Sonogashira cross-coupling has been reported, providing access to 3-deaza-3-alkyne adenosine derivatives. ${ }^{8,9,23}$

However, the use of nucleosides as substrates for crosscoupling reactions can be challenging due to the presence of potentially labile glycosidic bonds or nucleophilic functional groups that have to be protected to achieve the compatibility with many organometallic reagents, as reflected by the reported examples of Negishi and Kumada reactions for the introduction of alkyl or benzyl substituents. ${ }^{24-27}$ Given the importance of modified nucleobases itself, the method that would allow a

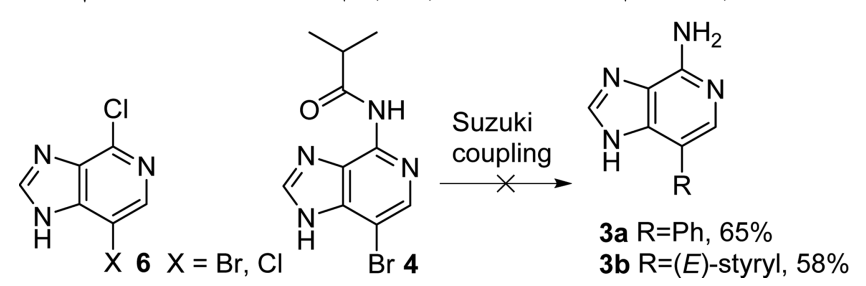

Received: August 9, 2017

Accepted: October 6, 2017

Published: October 20, 2017 
to obtain the 3-iodo-3-deazaadenine 2 and observe its acceptable reactivity under Suzuki cross-coupling conditions using the $\mathrm{Pd}(\mathrm{OAc})_{2} / 3,3^{\prime}, 3^{\prime \prime}$-phosphanetriyltris(benzenesulfonic acid) trisodium salt (TPPTS) catalyst system, a general method developed for aqueous coupling reactions of halogenated purine/pyrimidine nucleobases and nucleosides. ${ }^{4,26,28}$ The reactions of 2 with phenylboronic acid and trans-2-phenylvinylboronic acid afforded compounds $3 a$ and $3 b$ with 65 and $58 \%$ yield, respectively (Scheme 1 ).

Despite the sufficient results obtained for Suzuki crosscoupling of $\mathbf{2}$ with model aryl/vinylboronic acids, this condition failed in the attempt to produce an alkyl analogue with model ethylboronic acid, similarly as reported by other authors. ${ }^{26}$ The reactivity of $\mathbf{2}$ can be hampered by its low solubility in organic solvents and the presence of active nucleophilic nitrogens. When the amino group at C6 was protected as an isobutyryl amide (the established purine protecting group), the more soluble $N$-(7-bromo-1H-imidazo[4,5-c]pyridin-4-yl)isobutyramide 4 was obtained (Scheme 1). ${ }^{15}$ Various Suzuki coupling conditions of $\mathbf{4}$ with phenyl- and isobutylboronic acids were investigated, involving metal catalysts, such as $\mathrm{Pd}\left(\mathrm{PPh}_{3}\right)_{4}$, $\mathrm{Pd}_{2}(\mathrm{dba})_{3}, \mathrm{PddppfCl}_{2}$, and $\mathrm{NiCl}_{2}(\mathrm{dme})$; ligands, such as $\mathrm{PCy}_{3}$, $(t-\mathrm{Bu})_{2} \mathrm{PMeHBF}_{4}$, and SPhos; and bases, such as $\mathrm{K}_{2} \mathrm{CO}_{3}$, $\mathrm{Cs}_{2} \mathrm{CO}_{3}, \mathrm{~K}_{3} \mathrm{PO}_{4}$, and $\mathrm{KO} t-\mathrm{Bu}$ in ethereal or alcoholic solvents. $^{29-33}$ Typically, the unreacted starting material was recovered from the reaction mixtures, highlighting the lack of reactivity of 4 . Also, the liability of amide protecting group prohibited the use of aqueous coupling conditions utilizing bases such as carbonates.

We have also evaluated the possibility of using a commercial C6-chloro (5) and the known C6-azide ${ }^{34}$ (5b) purines as starting materials amenable for further amination and reduction, respectively, to access 3-deazaadenine. However, attempts to install a halide at C3 (compound 6, Scheme 1) have failed, precluding further evaluation.

As the electron-withdrawing groups at C6 (chloride, amide, or azide) were shutting off the reactivity of $\mathrm{C} 3$ position, we hypothesized that the use of electronically more neutral protecting groups will promote the solubility of $\mathbf{1}$ and retain its reactivity toward cross-coupling reactions. Unfavorably, the direct attempts to react $\mathbf{5}$ with bisbenzylamines to produce the desired cross-coupling partner of type 13 (Scheme 2) failed

\section{Scheme 2. Synthesis of Compound 13}
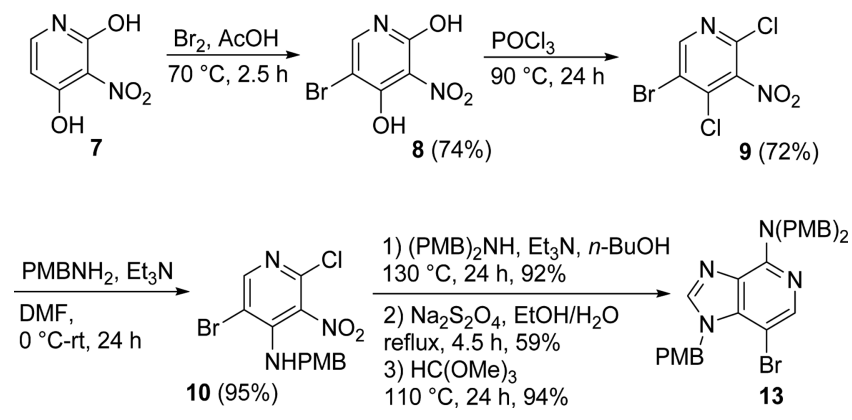

even under harsh conditions (e.g., $140{ }^{\circ} \mathrm{C}$, neat or dimethylformamide (DMF)/ $\left.\mathrm{K}_{2} \mathrm{CO}_{3}\right)$, reflecting the evident low reactivity of this substrate toward direct displacement of chlorine atom. ${ }^{12,34} \mathrm{We}$ decided to investigate the catalytic aminations with bis(4-methoxybenzylamine $)\left((\mathrm{PMB})_{2} \mathrm{NH}\right)$ on 5. In parallel, the catalytic amination of PMB-protected analogue was investigated, considering the reported challenges for modifications of unprotected imidazoles. ${ }^{35}$ It should be noted that $\mathrm{PMB}$ protection of $5\left(\mathrm{PMBCl}, \mathrm{K}_{2} \mathrm{CO}_{3}, \mathrm{~N}, \mathrm{~N}\right.$ dimethylacetamide (DMA), $45{ }^{\circ} \mathrm{C}, 24 \mathrm{~h}, 96 \%$ yield) yielded a 1.6:1 mixture of N9- and N7-PMB-protected products that was used directly. ${ }^{36}$ Several literature conditions applicable for chloroarenes, 6-halopurines, and their nucleosides were investigated. ${ }^{37-42}$ RuPhos and its Pd-bound precatalyst in the presence of $\mathrm{NaOt}$-Bu in tetrahydrofuran $(\mathrm{THF})^{41}$ have been shown to be particularly successful for the reactions of nonactivated heretoaryl chlorides with secondary amines. Under these conditions, up to $19 \%$ of N9-PMB-protected product (identical to $\mathbf{1 3 - H}$, Experimental Section) was obtained, albeit with higher catalyst loading (6 mol \%) and prolonged reaction time $(43 \mathrm{~h})$. However, a significant decomposition was observed. The use of LiHMDS instead of $\mathrm{NaO} t$-Bu led to the exclusive decomposition of both protected and nonprotected 5. Next, $\mathrm{Pd}(\mathrm{OAc})_{2}$ was tested in combination with ligands, such as BINAP, SPhos, and XPhos, in the presence of $\mathrm{Cs}_{2} \mathrm{CO}_{3}$ or $\mathrm{NaOt}$-Bu in solvents, such as toluene, THF, dioxane, and DMF. ${ }^{37-40,42}$ Significant decomposition was observed in the majority of cases, but no product formation. Some level of success was achieved with the combination of $\mathrm{Pd}(\mathrm{OAc})_{2}$ ( 0.1 equiv) and SPhos ( 0.2 equiv) in the presence of $\mathrm{NaOt}$-Bu in toluene $\left(110^{\circ} \mathrm{C}, 22 \mathrm{~h}\right) .13-\mathrm{H}$ was isolated in $21 \%$ yield, reflecting the low reactivity of heteroaryl chlorides with secondary amines. ${ }^{40,41}$ For practical purposes, we have not investigated this reaction further.

To overcome hurdles posed by the limited reactivity of the tested substrates, we decided to construct the fully protected 3deazaadenine analogue from the cheap, available precursors, using a similar route as reported in the literature. ${ }^{15,43}$ The highly regioselective sequential substitutions of 4- and 2-chloro atoms of the known derivative $\mathbf{9}^{43}$ with 4-methoxybenzylamine $\left(\mathrm{PMBNH}_{2}\right)$ followed by $(\mathrm{PMB})_{2} \mathrm{NH}$ produced compound $\mathbf{1 1}$ (Experimental Section), and upon further reduction of the nitro group and cyclization, we were able to obtain the target 3deazaadenine precursor (13) with the exclusive N9-PMB protection and $26 \%$ overall yield in six steps from a commercial 3-nitropyridine-2,4-diol 7 (Scheme 2). The length of the synthetic route is similar to that of $\mathbf{1}^{15}$ but offers access to the fully protected soluble starting material amenable to functionalization.

Gratifyingly, a variety of different coupling conditions involving 13 were successfully demonstrated, as shown in Table 1, including the examples of reactions such as Suzuki ${ }^{43,44}$ (entries 1-5), Heck $^{45}$ (entries 6 and 7), Sonogashira ${ }^{8,23}$ (entry $8), \mathrm{Kumada}^{46}$ (entries 9 and 10), Negishi (entries 11-14), ${ }^{47}$ and the nickel-catalyzed reductive couplings of alkyl halides recently developed by the Weix group (entry 15). ${ }^{48}$

The Suzuki couplings could be accomplished with aromatic, alkenyl, and alkyl boronic acids (entries 1-5). Both electronrich and electron-deficient alkenes were tolerated under the Heck conditions (entries 6 and 7). Sonogashira coupling with phenylacetylene proceeded with high efficiency (89\%, entry 8 ).

The formation of alkyl derivatives, with the challenging substrates containing $\beta$-hydrogens, such as alkylboronic acids or ethyl 4-bromobutyrate, was less efficient (29-35\%, entries 3-5 and 15) and accompanied by a significant hydrodebromination reaction, indicating the extent of the undesired $\beta$-H elimination. This byproduct $(\mathbf{1 3}-\mathbf{H})$ could be subjected to halogenation, for example, by the treatment of crude reaction mixtures with $\mathrm{N}$ bromosuccinimide (NBS)/NIS, facilitating a chromatographic separation of the cross-coupled product 14, while the 
Table 1. Transformation Scope for the Metal-Catalyzed Couplings of 13<smiles>[Y4]c1cnc(N(CC)CCC)c2ncn([R15])c12</smiles>

\begin{tabular}{|c|c|c|c|c|}
\hline entry & substrate & cond. $^{a}$ & product & $\begin{array}{c}\text { yield } \\
(\%)\end{array}$ \\
\hline 1 & $\mathrm{PhB}(\mathrm{OH})_{2}$ & A & $14 a, R=P h$ & 91 \\
\hline 2 & $\mathrm{PhCH}=\mathrm{CH}_{2} \mathrm{~B}(\mathrm{OH})_{2}$ & A & 14b, $\mathbf{R}=(E)$-styryl & 79 \\
\hline 3 & $\mathrm{Ph}\left(\mathrm{CH}_{2}\right)_{2} \mathrm{~B}(\mathrm{OH})_{2}$ & B & 14c, $\mathrm{R}=\left(\mathrm{CH}_{2}\right)_{2} \mathrm{Ph}$ & 35 \\
\hline 4 & $\mathrm{EtB}(\mathrm{OH})_{2}$ & B & 14d, $R=E t$ & 31 \\
\hline 5 & $i-\mathrm{BuB}(\mathrm{OH})_{2}$ & B & $14 \mathrm{e}, \mathrm{R}=i-\mathrm{Bu}$ & 29 \\
\hline 6 & $\mathrm{PhCH}=\mathrm{CH}_{2}$ & $\mathrm{C}$ & 14b, $\mathrm{R}=(E)$-styryl & 53 \\
\hline 7 & $\mathrm{CH}_{2}=\mathrm{CHCO}_{2} \mathrm{Me}$ & $\mathrm{C}$ & $\mathbf{1 4 f}, \mathbf{R}=(E)$-acrylate & $57^{b}$ \\
\hline 8 & $\mathrm{PhC} \equiv \mathrm{CH}$ & $\mathrm{D}$ & $14 \mathrm{~g}, \mathrm{R}=\mathrm{C} \equiv \mathrm{CPh}$ & 89 \\
\hline 9 & $\mathrm{Al}(\mathrm{Me})_{3}$ & $\mathrm{E}$ & $14 \mathrm{~h}, \mathrm{R}=\mathrm{Me}$ & 87 \\
\hline 10 & $\mathrm{BnMgCl}$ & $\mathrm{E}$ & $14 i, R=B n$ & 45 \\
\hline 11 & $\mathrm{Ph}\left(\mathrm{CH}_{2}\right)_{2} \mathrm{ZnX}$ & $\mathrm{F}$ & 14c, $\mathrm{R}=\left(\mathrm{CH}_{2}\right)_{2} \mathrm{Ph}$ & 77 \\
\hline 12 & $\mathrm{EtZnX}$ & $\mathrm{F}$ & 14d, R = Et & 76 \\
\hline 13 & $i$-BuZnX & $\mathrm{F}$ & $14 \mathrm{e}, \mathrm{R}=i-\mathrm{Bu}$ & 85 \\
\hline 14 & $i-\operatorname{PrZnX}$ & $\mathrm{F}$ & $\mathbf{1 4} \mathbf{j}, \mathrm{R}=i-\operatorname{Pr}$ & $86^{c}$ \\
\hline 15 & $\mathrm{Br}\left(\mathrm{CH}_{2}\right)_{3} \mathrm{CO}_{2} \mathrm{Et}$ & G & $14 \mathrm{k}, \mathrm{R}=\left(\mathrm{CH}_{2}\right)_{3} \mathrm{CO}_{2} \mathrm{Et}$ & $32^{b}$ \\
\hline
\end{tabular}

${ }^{a}$ Condition $\mathrm{A}$ : $\mathrm{Ar}$ or vinylB $(\mathrm{OH})_{2}$ (1.5 equiv), $\mathrm{Cs}_{2} \mathrm{CO}_{3}$ (2 equiv), $\mathrm{Pd}\left(\mathrm{PPh}_{3}\right)_{4}$ (0.1 equiv), dioxane $/ \mathrm{H}_{2} \mathrm{O}(2 / 1), \mathrm{Ar}, 90{ }^{\circ} \mathrm{C}, 6-16 \mathrm{~h}$; condition B: $\operatorname{AlkylB}(\mathrm{OH})_{2}$ (1.1-1.5 equiv), $\mathrm{K}_{2} \mathrm{CO}_{3}$ (3 equiv), $\mathrm{Pd}\left(\mathrm{PPh}_{3}\right)_{4}$ (0.1 equiv), dry dioxane, $\mathrm{Ar}, 90{ }^{\circ} \mathrm{C}, 72 \mathrm{~h}$; condition C: styrene or methyl acrylate (5 equiv), $\mathrm{Et}_{3} \mathrm{~N}$ (7 equiv), $\mathrm{PPh}_{3}$ ( 0.5 equiv), $\mathrm{Pd}(\mathrm{OAc})_{2}$ (0.1 equiv), dry $\mathrm{CH}_{3} \mathrm{CN}, \mathrm{Ar}, 90^{\circ} \mathrm{C}, 36 \mathrm{~h}$; condition $\mathrm{D}$ : phenylacetylene (1.5 equiv), $\mathrm{Pd}\left(\mathrm{PPh}_{3}\right)_{2} \mathrm{Cl}_{2}$ (0.1 equiv), $\mathrm{CuI}(0.1$ equiv), dry $\mathrm{DMF} / \mathrm{Et}_{3} \mathrm{~N}(2 / 1), \mathrm{Ar}, 80^{\circ} \mathrm{C}, 24 \mathrm{~h}$; condition $\mathrm{E}: \mathrm{Al}(\mathrm{Me})_{3}$ or $\mathrm{BnMgCl}$ solution (3-3.3 equiv), $\mathrm{Pd}\left(\mathrm{PPh}_{3}\right)_{4}$ (0.1 equiv), dry THF, $\mathrm{Ar}, 75{ }^{\circ} \mathrm{C}, 4 \mathrm{~h}$; condition $\mathrm{F}$ : $\mathrm{ZnCl}_{2}(0.5 \mathrm{M}$ in THF, 5.7 equiv), AlkylMgX solution ( $\mathrm{X}=\mathrm{Br}$ or $\mathrm{Cl}, 8.6$ equiv), $\mathrm{Ar}, \mathrm{rt}, 1 \mathrm{~h}$, then 13 (1 equiv), $\mathrm{PddppfCl}_{2}$ (0.1 equiv), $\mathrm{Ar}, \mathrm{rt}, 21-29 \mathrm{~h}$; condition G: $\mathrm{Br}\left(\mathrm{CH}_{2}\right)_{3} \mathrm{CO}_{2} \mathrm{Et}$ (1.1 equiv), $\mathrm{Zn}$ (2 equiv), 4,4'-dimethoxy-2,2'bipyridine (0.1 equiv), $\mathrm{NiI}_{2}$ ( 0.13 equiv), pyridine (0.1 equiv), $\mathrm{NaI}$ ( 0.25 equiv), dry DMA, Ar, rt, 5 min, then $60^{\circ} \mathrm{C}, 20 \mathrm{~h} .{ }^{b}$ Yield isolated after treatment of the crude mixture with $\mathrm{N}$-iodosuccinimide (NIS) and separation of 13-I (for details, see Experimental Section). ${ }^{c}$ Contains $\sim 20 \%$ of $n$-propyl impurity.

haloderivative 13/13-I could be recovered (see Experimental Section). The iodo analogue 13-I obtained this way offered no selectivity enhancement for alkylations using conditions B or F. Propitiously, simple alkyl derivatives could be obtained with improved yields (45-87\%) through Kumada-type couplings with substrates such as trimethylaluminum and benzylmagnesium chloride (entries 9 and 10). Ultimately, modified Negishi conditions allowed the access to a variety of primary alkyl derivatives with notably higher yields than those obtained through Suzuki protocol (entries $11-13$ vs $3-5$ ). In the case of challenging isopropyl derivative, we observed up to $20 \%$ of the known isopropyl to $n$-propyl isomerization (entry 14). ${ }^{49}$ Interestingly, our Negishi protocol provided satisfying and consistent results only when an excess of Grignard reagent against an overstoichiometric amount of zinc chloride was used, which helped to improve the solubility of the intermediate organozinc species. This observation seems to be in accord with the works by the Organ group that unveiled the mechanisms involving organozinc reagents in Negishi cross-couplings. ${ }^{50,51}$
Clearly, the fully protected nucleobase $\mathbf{1 3}$ allows the use of a broad scope of coupling conditions with not only the formation of saturated and unsaturated $\mathrm{C}-\mathrm{C}$ bonds, but also the introduction of functional groups, to access the C3-modified 3-deazaadenine derivatives. These results pinpoint appropriateness of the PMB as a protecting group with suitable electronic and chemical properties that allowed to achieve the desired reactivity of 13 among the other tested 3-deaza-3-haloadenine substrates.

We further aimed to elaborate the products to the protected phosphoramidites to verify their compatibility with producing building blocks for solid-phase DNA synthesis. The route to phosphoramidites is exemplified by the synthesis of compound 20i (Scheme 3). We successfully optimized the procedure for complete deprotection of benzyl derivative $14 \mathbf{i}$ affording modified purine $15 \mathbf{i}^{52}$ The known problem of selectivity for purine glycosylations prompted us to use the tetramethylsuccinimide directing/protecting group, developed by the McLaughlin group, ${ }^{53}$ to increase the selectivity toward the desired N9 $\beta$ glycosylation. The crude salt $\mathbf{1 5 i}$ was converted accordingly to the corresponding imide 16i through the reported two-step procedure using tetramethylsuccinic anhydride $\left(\mathrm{Me}_{4} \mathrm{SA}\right) .{ }^{53}$ The imide 16i was subjected to glycosylation with 1- $(\alpha)$-chloro-3,5di-O-( $p$-toluoyl)-2-deoxy-D-ribose, affording the desired N9 $\beta$ nucleoside $17 \mathbf{i}$ in $39 \%$ yield. The configuration of nucleoside 17i was unambiguously confirmed by the nuclear Overhauser enhancement spectroscopy (NOESY) experiment (Figure S1, Supporting Information). It was then elaborated to the corresponding phosphoramidite 20i through standard methods (Scheme 3). Analogously, two other phosphoramidites 20d and 20e were prepared from $14 \mathrm{~d}$ and $14 \mathrm{e}$, ethyl and isobutyl analogues, respectively. All three phosphoramidites were successfully used in solid-phase DNA synthesis, and further studies are in progress. Interestingly, the preparation of the corresponding phosphoramidite 20a from phenyl derivative 14a could not be achieved due to the destabilizing effect of the $\mathrm{Ph}$ group on the glycosidic bond (see Experimental Section). We have also considered the possibility of the direct functionalization of nucleosides by an attempt to prepare a bromo analogue of $17 \mathbf{i}$ through the halogenation of the reported nonmodified 3-deazaadenine phosphoramidite. ${ }^{13}$ However, the reactions with NBS in $\mathrm{CH}_{2} \mathrm{Cl}_{2}$ or DMF were unsuccessful, likely due to the electronegative effect of the tetramethylsuccinimide group.

Additionally, the modified 3-deazaadenines could be readily converted to the corresponding 3-deazahypoxanthines, purine analogues of interest for medicinal chemistry, ${ }^{36,54}$ upon treatment with $\mathrm{NaNO}_{2}$ as exemplified by the reaction of crude salt $15 \mathrm{c}$ to produce $21 \mathrm{c}$ in $57 \%$ yield based on $14 \mathrm{c}$ (Scheme 4). ${ }^{55,56}$ This transformation further demonstrates the potential of our synthetic approach toward C3-modified purine scaffold.

\section{CONCLUSIONS}

This study illustrates the merit of a new fully protected 3bromo-3-deazaadenine derivative developed by us as a building block for the deliberate synthesis of 3-substituted 3deazaadenine and adenosine derivatives through metalcatalyzed cross-coupling reactions and selective N9 $\beta$ glycosylations. It should be expected that both modified purines and their nucleosides will be of interest for applications related to chemical biology, DNA studies, and medicinal chemistry. 
Scheme 3. Synthesis of Phosphoramidite 20i
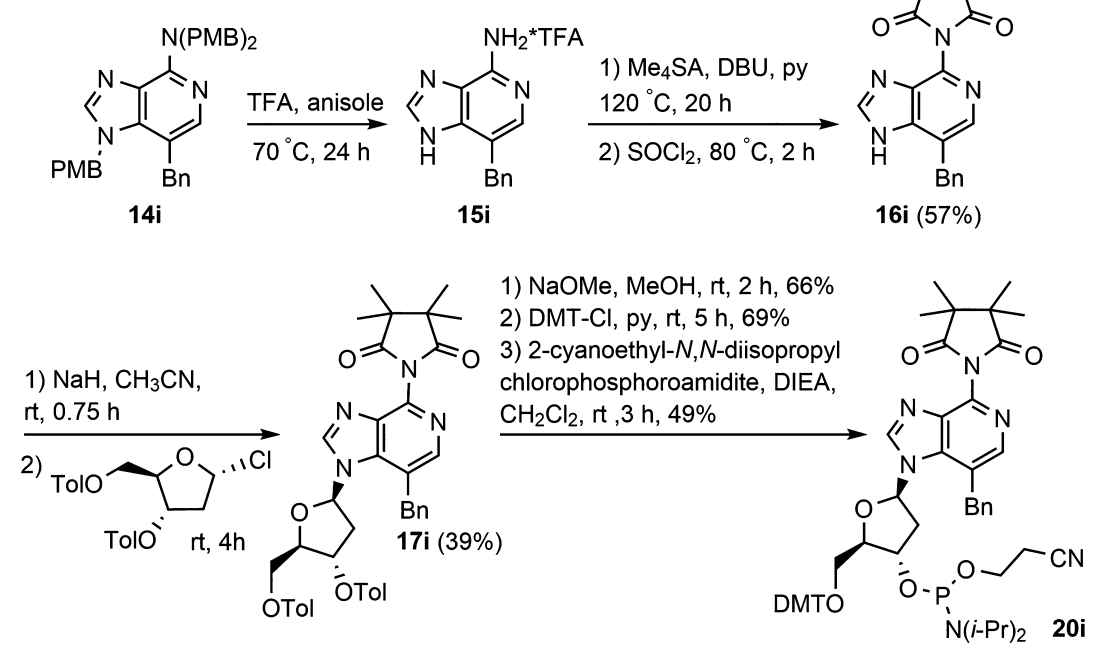

Scheme 4. Synthesis of 3-Deazahypoxanthine 21c<smiles>Nc1ncc(CC[PbH])c2[nH]cnc12</smiles>

aq. $\mathrm{NaNO}_{2}$, acetic acid acetone, rt, $5 \mathrm{~h}$

$15 c$

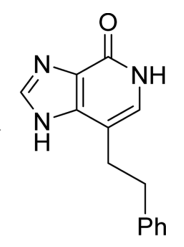

21c $(57 \%$ from 14c)

\section{EXPERIMENTAL SECTION}

General Methods. All reagents were used as received unless otherwise stated from Sigma-Aldrich, TCI America, Alfa Aesar, AK Scientific, and Chem-Impex International. 4-Chloro$1 H$-imidazo[4,5-c]pyridine was obtained from MolBridge. Bis(4-methoxybenzyl)amine and TPPTS were obtained from Ark Pharm. 1- $(\alpha)$-Chloro-3,5-di-O-( $p$-toluoyl)-2-deoxy-D-ribose was purchased from Berry \& Associates. Anhydrous methanol, pyridine, and $N, N$-dimethylacetamide (DMA) were obtained from Sigma-Aldrich. $N, N$-dimethylformamide (DMF) and 1,4-dioxane were dried and stored over $\mathrm{CaH}_{2}$ before use. Dry acetonitrile, dichloromethane, and tetrahydrofuran were dispensed from automated Innovative Technology Pure-Solv 400 Solvent Purification System. Analytical thin-layer chromatography was carried out on commercial SiliCycle SiliaPlate 0.2 mm F254 plates. Preparative silica chromatography was performed using SiliCycle SiliaFlash F60 40-63 $\mu \mathrm{m}$ (230$400 \mathrm{mesh}) .{ }^{1} \mathrm{H},{ }^{13} \mathrm{C}$, and ${ }^{31} \mathrm{P}$ NMR spectra were recorded at room temperature (rt) with a Varian Unity Inova $400 \mathrm{MHz}$ spectrometer. $\mathrm{CDCl}_{3}$, dimethyl sulfoxide (DMSO)- $d_{6}, \mathrm{CD}_{3} \mathrm{OD}$, acetone- $d_{6}$, and $\mathrm{D}_{2} \mathrm{O}$ were used as solvents and referenced to the corresponding residual solvent peaks (7.26 and $77.16 \mathrm{ppm}$ for $\mathrm{CDCl}_{3}$, respectively; 2.50 and $39.52 \mathrm{ppm}$ for DMSO- $d_{6}$, respectively; 3.31 and $49.0 \mathrm{ppm}$ for $\mathrm{CD}_{3} \mathrm{OD}$, respectively; 2.05 and $29.84 \mathrm{ppm}$ for acetone- $d_{6}$, respectively; and $4.79 \mathrm{ppm}$ for $\left.\mathrm{D}_{2} \mathrm{O}\right) .{ }^{57}$ The following abbreviations are used to indicate the multiplicity: s: singlet; $\mathrm{d}$ : doublet; $\mathrm{t}$ : triplet; $\mathrm{q}$ : quartet; $\mathrm{m}$ : multiplet; b: broad signal; app: approximate. The coupling constants are expressed in hertz $(\mathrm{Hz})$. The multiplicity of carbon atoms was determined by DEPT-135 experiment; Cq: quaternary carbon. Mass spectrometry (MS) data (electrospray ionization, ESI) were obtained using a Thermo Finnigan LCQ
Advantage Ion-Trap Mass Spectrometer. High-resolution (HR) MS data (ESI) were obtained using a Thermo Fisher Orbitrap Elite Hybrid Ion Trap-Orbitrap Mass Spectrometer in Chemical Advanced Resolution Methods (ChARM) Laboratory at Michigan Technological University.

Synthesis and Characterization Data. Compounds $\mathbf{1}^{15}$ $\mathbf{4},{ }^{15,22}$ and $\mathbf{5} \mathbf{b}^{34}$ were prepared according to the reported procedures.

7-lodo-1H-imidazo[4,5-c]pyridin-4-amine (2). To a suspension of amine 1 (536 mg, ca. $4 \mathrm{mmol})$ in dry DMF $(8 \mathrm{~mL})$, $\mathrm{N}$-iodosuccinimide (NIS) (1.125 g, $5 \mathrm{mmol}$ ) was added in one portion. A slightly exothermic reaction occurred, and the resulting dark solution was stirred at room temperature for 24 h. After $24 \mathrm{~h}$, the solution was added dropwise to EtOAc (100 $\mathrm{mL}$ ) with vigorous stirring, and the resulting solid was filtered and washed with EtOAc. The solid was then suspended in chloroform $(50 \mathrm{~mL})$ and vigorously stirred under reflux condenser at $70{ }^{\circ} \mathrm{C}$ overnight. After filtration and drying in air, 2 was obtained as a dark brown solid in $27 \%$ yield $(0.27 \mathrm{~g})$. HRMS (ESI): $m / z[\mathrm{M}+\mathrm{H}]^{+}$calcd for $\mathrm{C}_{6} \mathrm{H}_{4} \mathrm{~N}_{4} \mathrm{I}: 260.96373$; found: 260.96323. MS (ESI): $m / z, 261.2$ for $[\mathrm{M}+\mathrm{H}]^{+} .{ }^{1} \mathrm{H}$ NMR (400 MHz, DMSO- $\left.d_{6}\right): \delta, 8.49(\mathrm{~s}, 1 \mathrm{H}), 8.44$ (bs, 2H), $7.97(\mathrm{~s}, 1 \mathrm{H}) \mathrm{ppm}$. We were not able to obtain satisfactory ${ }^{13} \mathrm{C}$ NMR data in DMSO- $d_{6}$.

7-Phenyl-1H-imidazo[4,5-c]pyridin-4-amine (3a). This compound was synthesized according to the reported general procedures. $^{4,26}$ To a vial equipped with septa, a mixture of deionized water and acetonitrile $(2: 1,9 \mathrm{~mL})$ was added and bubbled with argon for $10 \mathrm{~min} .2(150 \mathrm{mg}, 0.58 \mathrm{mmol})$, phenylboronic acid ( $88 \mathrm{mg}, 0.72 \mathrm{mmol})$, palladium(II) acetate (7 mg, $0.029 \mathrm{mmol}$ ), TPPTS (41 $\mathrm{mg}, 0.072 \mathrm{mmol}$ ), and anhydrous sodium carbonate $(183 \mathrm{mg}, 1.7 \mathrm{mmol}$ ) were added, and the headspace of the vial was flushed with argon for $1 \mathrm{~min}$. The mixture was vigorously stirred at $100{ }^{\circ} \mathrm{C}$ for $7 \mathrm{~h}$. The mixture was then cooled and diluted with ethyl acetate $(50 \mathrm{~mL})$ and brine $(10 \mathrm{~mL})$. The phases were separated, and the aqueous phase was extracted with additional ethyl acetate $(3 \times$ $30 \mathrm{~mL})$. Combined organic extracts were dried with $\mathrm{MgSO}_{4}$. After filtration and concentration, the residue was purified by column chromatography on silica gel, eluting with $0-10 \%$ $\mathrm{MeOH}$ in $\mathrm{CH}_{2} \mathrm{Cl}_{2}$ to obtain $3 \mathrm{a}$ as a yellow solid in $65 \%$ yield (79 mg). HRMS (ESI): $m / z[\mathrm{M}+\mathrm{H}]^{+}$calcd for $\mathrm{C}_{12} \mathrm{H}_{11} \mathrm{~N}_{4}$ : 
211.09838; found: 211.09680 . MS (ESI): $m / z, 211.3$ for $[\mathrm{M}+$ $\mathrm{H}]^{+} .{ }^{1} \mathrm{H}$ NMR (400 MHz, DMSO- $\left.d_{6}\right): \delta, 8.20(\mathrm{~s}, 1 \mathrm{H}), 7.85(\mathrm{~s}$, $2 \mathrm{H}), 7.73(\mathrm{~b}, 2 \mathrm{H}), 7.48-7.44(\mathrm{~m}, 2 \mathrm{H}), 7.34-7.30(\mathrm{~m}, 1 \mathrm{H})$, $6.46(\mathrm{~b}, 2 \mathrm{H}) \mathrm{ppm} .{ }^{13} \mathrm{C}$ NMR (100 MHz, DMSO-d $\left.)_{6}\right): \delta, 141.3$, 137.5, 136.1, 128.7, 127.3, 126.5 ppm.

(E)-7-Styryl-1H-imidazo[4,5-c]pyridin-4-amine (3b). This compound was synthesized in a similar fashion to $3 a$. To a vial equipped with septa, a mixture of deionized water and acetonitrile $(2: 1,6 \mathrm{~mL})$ was added and bubbled with argon for 10 min. 2 (100 mg, $0.38 \mathrm{mmol})$, trans-2-phenylvinylboronic acid $(71 \mathrm{mg}, 0.48 \mathrm{mmol})$, palladium(II) acetate $(5 \mathrm{mg}, 0.019$ $\mathrm{mmol})$, TPPTS (28 mg, $0.048 \mathrm{mmol})$, and anhydrous sodium carbonate $(122 \mathrm{mg}, 1.2 \mathrm{mmol})$ were added, and the headspace of the vial was flushed with argon for $1 \mathrm{~min}$. The mixture was vigorously stirred at $100{ }^{\circ} \mathrm{C}$ for $16 \mathrm{~h}$. The mixture was then cooled and diluted with ethyl acetate $(40 \mathrm{~mL})$ and brine $(10$ $\mathrm{mL}$ ). The phases were separated, and the aqueous phase was extracted with additional ethyl acetate $(3 \times 20 \mathrm{~mL})$. Combined organic extracts were dried with $\mathrm{MgSO}_{4}$. After filtration and concentration, the residue was purified by column chromatography on silica gel, eluting with $0-10 \% \mathrm{MeOH}$ in $\mathrm{CH}_{2} \mathrm{Cl}_{2}$ to obtain $3 \mathrm{~b}$ as a cream solid in $58 \%$ yield $(52 \mathrm{mg}$ ). HRMS (ESI): $m / z[\mathrm{M}+\mathrm{H}]^{+}$calcd for $\mathrm{C}_{14} \mathrm{H}_{13} \mathrm{~N}_{4}$ : 237.11403; found: 211.11269. ${ }^{1} \mathrm{H}$ NMR (400 MHz, DMSO- $\left.d_{6}\right): \delta, 8.28(\mathrm{~s}, 1 \mathrm{H})$, 7.89 (s, 1H), 7.58-7.56 (m, 2H), 7.38-7.31 (m, 4H), 7.23$7.20(\mathrm{~m}, 1 \mathrm{H}), 6.52(\mathrm{~b}, 2 \mathrm{H}) \mathrm{ppm} .{ }^{13} \mathrm{C}$ NMR (100 MHz, DMSO- $\left.d_{6}\right): \delta, 141.1,139.7,138.2,128.6,126.8,125.8,124.0$ ppm.

Synthesis of 13. Compounds 8 and 9 were prepared by modification of the reported procedures. ${ }^{43}$

5-Bromo-3-nitropyridine-2,3-diol (8). To the suspension of 3-nitropyridine-2,4-diol $7(10 \mathrm{~g}, 64.1 \mathrm{mmol})$ in glacial acetic acid $(100 \mathrm{~mL})$, bromine $(4.6 \mathrm{~mL}, 90 \mathrm{mmol})$ was added in one portion, and the mixture was stirred at $70{ }^{\circ} \mathrm{C}$ for $2.5 \mathrm{~h}$. The reaction mixture was then cooled and poured onto $300 \mathrm{~mL}$ of crushed ice, stirred vigorously for $30 \mathrm{~min}$, and chilled in the freezer for $1 \mathrm{~h}$. The precipitated solids were filtered on paper, washed with a small volume of ice-cold water several times and then with ethanol $(3 \times 15 \mathrm{~mL})$, and dried in air. 8 was obtained as a yellow solid in $74 \%$ yield $(11.2 \mathrm{~g}) .{ }^{1} \mathrm{H}$ NMR (400 MHz, DMSO- $\left.d_{6}\right): \delta, 7.86(\mathrm{~s}, 1 \mathrm{H})$ ppm. ${ }^{13} \mathrm{C}$ NMR $(100 \mathrm{MHz}$, DMSO- $\left.d_{6}\right): \delta$, 159.1, 155.6, 138.6, 128.2, 94.0 ppm.

5-Bromo-2,4-dichloro-3-nitropyridine (9). A suspension of $8(11.1 \mathrm{~g}, 47.4 \mathrm{mmol})$ in $\mathrm{POCl}_{3}(100 \mathrm{~mL})$ was stirred at $90{ }^{\circ} \mathrm{C}$ for $24 \mathrm{~h}$ under argon, an excess pressure being released for several times within the first few hours. Then, $\mathrm{POCl}_{3}$ was carefully distilled off under vacuum. The oily residue was diluted with $\mathrm{Et}_{2} \mathrm{O}(100 \mathrm{~mL})$, cooled on an ice bath, and crushed ice $(200 \mathrm{~mL})$ was carefully added (exothermic reaction). The phases were separated, aqueous phase was additionally extracted with $\mathrm{Et}_{2} \mathrm{O}(2 \times 50 \mathrm{~mL})$, and the combined organics were washed with brine and dried with $\mathrm{MgSO}_{4}$. After filtration and concentration, the residue was purified by column chromatography on silica gel, eluting with $0-10 \%$ EtOAc in hexanes to obtain 9 as a yellow oil that slowly solidified (9.27 g, $72 \%$ yield). ${ }^{1} \mathrm{H}$ NMR (400 MHz, $\left.\mathrm{CDCl}_{3}\right): \delta$, $8.68(\mathrm{~s}, 1 \mathrm{H}) \mathrm{ppm} .{ }^{13} \mathrm{C} \mathrm{NMR}\left(100 \mathrm{MHz}, \mathrm{CDCl}_{3}\right): \delta, 152.1$, 141.5, 137.8, $121.3 \mathrm{ppm}$.

5-Bromo-2-chloro-N-(4-methoxybenzyl)-3-nitropyridin-4amine (10). To the solution of $9(9.25 \mathrm{~g}, 34.3 \mathrm{mmol})$ in dry DMF $(50 \mathrm{~mL})$ at $0{ }^{\circ} \mathrm{C}$ under argon, 4-methoxybenzylamine $(4.7 \mathrm{~mL}, 36 \mathrm{mmol})$ was added in one portion, followed by dropwise addition of $\mathrm{Et}_{3} \mathrm{~N}(5.5 \mathrm{~mL}, 36 \mathrm{mmol})$ over $5 \mathrm{~min}$. The mixture was allowed to warm up to room temperature and stirred for $24 \mathrm{~h}$. The mixture was then diluted with EtOAc (300 $\mathrm{mL})$, washed with brine $(4 \times 100 \mathrm{~mL})$, and dried with $\mathrm{MgSO}_{4}$. After filtration, the solution was concentrated in vacuo to give a yellow solid that was triturated with hexanes to give $\mathbf{1 0}$ as a dark orange solid (12.1 g, 95\% yield). HRMS (ESI): $m / z[\mathrm{M}+$ $\mathrm{H}]^{+}$calcd for $\mathrm{C}_{13} \mathrm{H}_{12}{ }^{79} \mathrm{Br}^{35} \mathrm{ClN}_{3} \mathrm{O}_{3}$ : 371.97507; found: 371.97488. ${ }^{1} \mathrm{H}$ NMR (400 MHz, $\left.\mathrm{CDCl}_{3}\right): \delta, 8.23(\mathrm{~s}, 1 \mathrm{H})$, $7.24-7.22$ (d, $J=8.4,2 \mathrm{H}), 6.93-6.91(\mathrm{~d}, J=8.4,2 \mathrm{H}), 5.24$ (bs, $1 \mathrm{H}), 4.22-4.21(\mathrm{~d}, J=4.8,2 \mathrm{H}), 3.82(\mathrm{~s}, 3 \mathrm{H}) \mathrm{ppm} .{ }^{13} \mathrm{C} \mathrm{NMR}$ $\left(100 \mathrm{MHz}, \mathrm{CDCl}_{3}\right): \delta, 160.1(\mathrm{Cq}), 149.3,143.4(\mathrm{Cq}), 143.3$ (Cq), 129.7, $127.9(\mathrm{Cq}), 114.8,109.4(\mathrm{Cq}), 55.5,47.0\left(\mathrm{CH}_{2}\right)$ ppm.

5-Bromo- $N^{2}, N^{2}, N^{4}$-tris(4-methoxybenzyl)-3-nitropyridine2,4-diamine (11). A $250 \mathrm{~mL}$ Schlenk tube was charged with 10 (12.1 g, $32.6 \mathrm{mmol})$, bis(4-methoxybenzyl)amine (10.9 g, 42.4 $\mathrm{mmol}), n$-butanol $(100 \mathrm{~mL})$, and $\mathrm{Et}_{3} \mathrm{~N}(6 \mathrm{~mL}, 43.1 \mathrm{mmol})$. The mixture was heated at $130{ }^{\circ} \mathrm{C}$ for $24 \mathrm{~h}$. It was cooled, diluted with EtOAc $(400 \mathrm{~mL})$, washed with brine $(200 \mathrm{~mL})$, and dried with $\mathrm{MgSO}_{4}$. After filtration, the solution was concentrated to give a dark residue that was purified by column chromatography on silica gel, eluting with $0-15 \%$ EtOAc in hexanes to obtain 11 as a red foam (17.6 g, 92\% yield). HRMS (ESI): $m / z[\mathrm{M}+\mathrm{H}]^{+}$calcd for $\mathrm{C}_{29} \mathrm{H}_{30}{ }^{79} \mathrm{BrN}_{4} \mathrm{O}_{5}$ : 593.13999; found: 593.13894. ${ }^{1} \mathrm{H}$ NMR (400 $\mathrm{MHz}, \mathrm{CDCl}_{3}$ ): $\delta, 8.09$ (s, $1 \mathrm{H}), 7.21-7.18(\mathrm{~d}, J=8.8,2 \mathrm{H}), 7.08-7.05(\mathrm{~d}, J=8.8,4 \mathrm{H})$, $6.88-6.86(\mathrm{~d}, J=8.8,2 \mathrm{H}), 6.82-6.80(\mathrm{~d}, J=8.8,4 \mathrm{H}), 6.14-$ $6.12(\mathrm{t}, J=4.8,1 \mathrm{H}), 4.46-4.45(\mathrm{~d}, J=4.8,2 \mathrm{H}), 4.29(\mathrm{~s}, 4 \mathrm{H})$, $3.782(\mathrm{~s}, 3 \mathrm{H}), 3.778(\mathrm{~s}, 6 \mathrm{H}) \mathrm{ppm} .{ }^{13} \mathrm{C}$ NMR (100 MHz, $\left.\mathrm{CDCl}_{3}\right): \delta, 159.6(\mathrm{Cq}), 159.0(\mathrm{Cq}), 155.5(\mathrm{Cq}), 151.1,146.5$ $(\mathrm{Cq}), 129.7,129.5(\mathrm{Cq}), 129.4,129.2(\mathrm{Cq}), 126.0(\mathrm{Cq}), 114.5$, 113.9, $99.6(\mathrm{Cq}), 55.4,55.3,53.7\left(\mathrm{CH}_{2}\right), 49.2\left(\mathrm{CH}_{2}\right)$ ppm.

5-Bromo- $N^{2}, N^{2}, N^{4}$-tris(4-methoxybenzyl)pyridine-2,3,4-triamine (12). A $1 \mathrm{~L}$ round-bottom flask was charged with 11 $(16.7 \mathrm{~g}, 28.2 \mathrm{mmol})$, ethanol $(600 \mathrm{~mL})$, and deionized water $(300 \mathrm{~mL})$, followed by $\mathrm{Na}_{2} \mathrm{~S}_{2} \mathrm{O}_{4}(9.81 \mathrm{~g}, 56.4 \mathrm{mmol}, 2$ equiv). The mixture was heated at $85{ }^{\circ} \mathrm{C}$ under reflux condenser. Additional sodium hydrosulfite was added at $30 \mathrm{~min}$ intervals (overall, $4 \times 2$ equiv) over $2.5 \mathrm{~h}$. The mixture was then concentrated in vacuo to remove most of ethanol and diluted with EtOAc $(200 \mathrm{~mL})$. It was carefully neutralized with solid $\mathrm{NaHCO}_{3}$ (effervescence!) with vigorous stirring. The organic layer was separated, the aqueous phase was additionally extracted with EtOAc $(2 \times 150 \mathrm{~mL})$, and the combined organics were washed with brine $(100 \mathrm{~mL})$ and dried with $\mathrm{MgSO}_{4}$. After filtration and concentration, the residue was purified by column chromatography on silica gel, eluting with $0-60 \%$ EtOAc in hexanes, and the product was additionally triturated with hexanes containing some EtOAc to obtain 12 as a cream solid in $59 \%$ yield $(9.4 \mathrm{~g})$. This compound is somewhat unstable and should be used within few days. HRMS (ESI): $m$ / $z[\mathrm{M}+\mathrm{H}]^{+}$calcd for $\mathrm{C}_{29} \mathrm{H}_{32}{ }^{79} \mathrm{BrN}_{4} \mathrm{O}_{3}:$ 563.1658; found: 563.16396. ${ }^{1} \mathrm{H}$ NMR $\left(400 \mathrm{MHz}, \mathrm{CDCl}_{3}\right): \delta, 7.77(\mathrm{~s}, 1 \mathrm{H})$, $7.22-7.20(\mathrm{~d}, J=8.8,2 \mathrm{H}), 7.10-7.08(\mathrm{~d}, J=8.8,4 \mathrm{H}), 6.84-$ $6.82(\mathrm{~d}, J=8.8,2 \mathrm{H}), 6.81-6.79(\mathrm{~d}, J=8.8,4 \mathrm{H}), 4.25-4.24(\mathrm{~d}$, $J=6.8,2 \mathrm{H}), 4.14(\mathrm{~s}, 4 \mathrm{H}), 4.00(\mathrm{bs}, 2 \mathrm{H}), 3.78(\mathrm{~s}, 9 \mathrm{H}) \mathrm{ppm} .{ }^{13} \mathrm{C}$ NMR $\left(100 \mathrm{MHz}, \mathrm{CDCl}_{3}\right): \delta, 159.1(\mathrm{Cq}), 158.8(\mathrm{Cq}), 150.2$ (Cq), 139.8 (Cq), 138.3, 131.6 (Cq), 130.7 (Cq), 130.1, 129.9 (Cq), 129.2, 114.1, 113.7, 110.8 (Cq), 55.36, 55.34, 53.5 $\left(\mathrm{CH}_{2}\right), 48.7\left(\mathrm{CH}_{2}\right)$ ppm.

7-Bromo-N,N, 1-tris(4-methoxybenzyl)-1H-imidazo-[4,5-c]pyridin-4-amine (13). A $250 \mathrm{~mL}$ Schlenk tube was charged with $12(9.4 \mathrm{~g}, 16.7 \mathrm{mmol})$ and trimethyl orthoformate (150 
$\mathrm{mL})$. The mixture was heated at $110{ }^{\circ} \mathrm{C}$ for $24 \mathrm{~h}$ and concentrated in vacuo. The remaining residue was dissolved in the smallest possible volume of EtOAc, and hexanes was carefully added dropwise with stirring to cause slight turbidity. The mixture was chilled in the freezer at $-20{ }^{\circ} \mathrm{C}$ overnight, and the resulting precipitate was filtered, washed with hexanes, and dried in air to give $\mathbf{1 3}$ as an off-white to cream solid in $94 \%$ yield (8.96 g). HRMS (ESI): $m / z[\mathrm{M}+\mathrm{H}]^{+}$calcd for $\mathrm{C}_{30} \mathrm{H}_{30}{ }^{81} \mathrm{BrN}_{4} \mathrm{O}_{3}$ : 575.1481; found: 575.14530. ${ }^{1} \mathrm{H}$ NMR $\left(399.8 \mathrm{MHz}, \mathrm{CDCl}_{3}\right): \delta, 7.97(\mathrm{~s}, 1 \mathrm{H}), 7.62(\mathrm{~s}, 1 \mathrm{H}), 7.22-$ $7.20(\mathrm{~d}, J=8.8,4 \mathrm{H}), 7.13-7.10(\mathrm{~d}, J=8.8,2 \mathrm{H}), 6.90-6.87(\mathrm{~d}$, $J=8.8,2 \mathrm{H}), 6.84-6.82(\mathrm{~d}, J=8.8,4 \mathrm{H}), 5.65(\mathrm{~s}, 2 \mathrm{H}), 5.13(\mathrm{~s}$, $4 \mathrm{H}), 3.80(\mathrm{~s}, 3 \mathrm{H}), 3.78(\mathrm{~s}, 6 \mathrm{H}) \mathrm{ppm} .{ }^{13} \mathrm{C}$ NMR $(100 \mathrm{MHz}$, $\left.\mathrm{CDCl}_{3}\right): \delta, 159.6(\mathrm{Cq}), 158.7(\mathrm{Cq}), 151.6(\mathrm{Cq}), 143.1,141.0$, $136.6(\mathrm{Cq}), 131.2(\mathrm{Cq}), 129.5(\mathrm{Cq}), 129.2,128.5,128.4(\mathrm{Cq})$, $114.5,113.9,89.0(\mathrm{Cq}), 55.44,55.38,49.8\left(\mathrm{CH}_{2}\right), 49.0\left(\mathrm{CH}_{2}\right)$ ppm.

Cross-Coupling Reactions of 13. General Conditions A. ${ }^{43}$ A solution of $13(0.25-3.5 \mathrm{mmol}, 1$ equiv) in 2:1 dioxane/ deionized water mixture (ca. $12 \mathrm{~mL} / \mathrm{mmol}$ ) was placed in a Schlenk tube or a vial equipped with septa. The mixture was bubbled with argon for ca. $1 \mathrm{~min} / \mathrm{mL}$. Aryl or vinylboronic acid (1.5 equiv), tetrakis(triphenylphosphine)palladium (0) (0.1 equiv), and anhydrous cesium carbonate ( 2 equiv) were added, and the mixture was bubbled with argon for few more minutes and heated at $90{ }^{\circ} \mathrm{C}$ for $6-16 \mathrm{~h}$ with vigorous stirring. It was cooled and diluted with equal volumes of $\mathrm{CH}_{2} \mathrm{Cl}_{2}$ and 1:1 water/brine, the phases were separated, and the aqueous phase was extracted twice with $\mathrm{CH}_{2} \mathrm{Cl}_{2}$. The combined organic extracts were dried with $\mathrm{MgSO}_{4}$. After filtration and concentration, the products were purified by column chromatography on silica gel eluting with $0-20 \%$ EtOAc in hexanes.

General Conditions $B{ }^{44}$ To a flame-dried vial equipped with septa, dry dioxane (ca. $7 \mathrm{~mL} / \mathrm{mmol}$ ) was added and bubbled with argon for ca. $1 \mathrm{~min} / \mathrm{mL}$. Compound 13 (0.25-3.5 mmol, 1 equiv), alkylboronic acid (1.1-1.5 equiv), tetrakis(triphenylphosphine)palladium( 0 ) (0.1 equiv), and anhydrous potassium carbonate ( 3 equiv) were added. The mixture was bubbled with argon for few more minutes and heated at $90{ }^{\circ} \mathrm{C}$ for $72 \mathrm{~h}$ with vigorous stirring. It was cooled and filtered through Celite and washed with $\mathrm{CH}_{2} \mathrm{Cl}_{2}$. After concentration, the products were purified by column chromatography on silica gel eluting with $0-20 \%$ EtOAc in hexanes.

General Conditions $C^{45}$ To a flame-dried vial equipped with septa, dry acetonitrile $(3.5 \mathrm{~mL})$ was added and bubbled with argon for ca. $1 \mathrm{~min} / \mathrm{mL}$. Compound 13 (0.25 mmol, 1 equiv), triphenylphosphine ( 0.5 equiv), and palladium(II) acetate (0.1 equiv) were added, followed by an olefin (5 equiv) and triethylamine ( 7 equiv), and the mixture was bubbled with argon for few more minutes and heated at $90{ }^{\circ} \mathrm{C}$ for $36 \mathrm{~h}$ with vigorous stirring. It was cooled, diluted with $\mathrm{CH}_{2} \mathrm{Cl}_{2}(50 \mathrm{~mL})$, washed with aqueous $\mathrm{NH}_{4} \mathrm{Cl}(2 \times 25 \mathrm{~mL})$, and dried with $\mathrm{MgSO}_{4}$. After filtration and concentration, the products were purified by column chromatography on silica gel eluting with $0-40 \%$ EtOAc in hexanes. The procedure for separation of dehalogenated byproduct: the crude mixture obtained after the extractive workup was redissolved in $\mathrm{CH}_{2} \mathrm{Cl}_{2}(10 \mathrm{~mL})$, and NIS (ca. 0.6 equiv) was added. After stirring at room temperature for $2 \mathrm{~h}$, the mixture was diluted with $\mathrm{CH}_{2} \mathrm{Cl}_{2}(50 \mathrm{~mL})$, washed with brine containing sodium thiosulfate $(25 \mathrm{~mL})$, and dried with $\mathrm{MgSO}_{4}$. After filtration and concentration, the products were purified by column chromatography on silica gel eluting with $0-40 \%$ EtOAc in hexanes. 13-I eluted first.

General Conditions $D .^{23}$ To a flame-dried vial equipped with septa, dry DMF $(5 \mathrm{~mL})$ and triethylamine $(2.5 \mathrm{~mL})$ were added and bubbled with argon for ca. $1 \mathrm{~min} / \mathrm{mL}$. Compound 13 ( 0.25 mmol, 1 equiv), $\mathrm{CuI}$ ( 0.1 equiv), and bis(triphenylphosphine)palladium(II) dichloride (0.1 equiv) were added, followed by phenylacetylene (1.5 equiv). The mixture was bubbled with argon for few more minutes and heated at $80{ }^{\circ} \mathrm{C}$ for $24 \mathrm{~h}$ with vigorous stirring. It was cooled, quenched with saturated aqueous $\mathrm{NH}_{4} \mathrm{Cl}(10 \mathrm{~mL})$, diluted with EtOAc $(10 \mathrm{~mL})$, washed with brine $(3 \times 10 \mathrm{~mL})$, and dried with $\mathrm{MgSO}_{4}$. After filtration and concentration, the products were purified by column chromatography on silica gel eluting with $0-20 \%$ EtOAc in hexanes.

General Conditions $E^{46}$ To a flame-dried vial equipped with septa, dry THF $(6 \mathrm{~mL})$ was added and bubbled with argon for ca. $1 \mathrm{~min} / \mathrm{mL}$. Compound $13(0.25 \mathrm{mmol}, 1$ equiv) and tetrakis(triphenylphosphine)palladium(0) (0.1 equiv) were added, followed by trimethylaluminum or benzylmagnesium chloride solutions (3-3.3 equiv), and the mixture was stirred at room temperature for $15 \mathrm{~min}$ and then heated at $80{ }^{\circ} \mathrm{C}$ for $4 \mathrm{~h}$ with vigorous stirring. It was cooled, carefully quenched with $\mathrm{Et}_{2} \mathrm{O}(30 \mathrm{~mL})$, washed with saturated aqueous $\mathrm{NH}_{4} \mathrm{Cl}(30$ $\mathrm{mL}$ ), and dried with $\mathrm{MgSO}_{4}$. After filtration and concentration, the products were purified by column chromatography on silica gel eluting with $0-40 \%$ EtOAc in hexanes.

General Conditions $F^{58}$ To a flame-dried vial equipped with septa, was added a solution of $\mathrm{ZnCl}_{2}(0.5 \mathrm{M}$ in THF, 5.7 equiv), followed by dropwise addition of Grignard reagent solution (8.6 equiv), and the mixture was stirred under argon for $1 \mathrm{~h}$. Then, compound 13 (0.175-0.7 mmol, 1 equiv) and [1,1'-bis(diphenylphosphino)ferrocene]-dichloropalladium(II) ( 0.1 equiv) were added, and the mixture was stirred at room temperature under argon for overall $21-29 \mathrm{~h}$. It was carefully quenched with $\mathrm{Et}_{2} \mathrm{O}(30-50 \mathrm{~mL})$, washed with equal volume of saturated aqueous $\mathrm{NH}_{4} \mathrm{Cl}$, and dried with $\mathrm{MgSO}_{4}$. After filtration and concentration, the products were purified by column chromatography on silica gel eluting with $0-20 \%$ EtOAc in hexanes.

General Conditions $G^{48}$ To a flame-dried vial equipped with septa, were added sequentially $\mathrm{NiI}_{2}$ (0.065 mmol, 0.13 equiv), 4,4'-dimethoxy-2,2'-bipyridine ( $0.05 \mathrm{mmol}, 0.1$ equiv), $\mathrm{NaI}$ ( $0.125 \mathrm{mmol}, 0.25$ equiv), 13 ( $0.5 \mathrm{mmol}, 1$ equiv), dry DMA $(2 \mathrm{~mL})$, pyridine $(5 \mu \mathrm{L})$, ethyl 4-bromobutyrate $(0.55$ mmol, 1.1 equiv), and $\mathrm{Zn}$ powder ( $1 \mathrm{mmol}, 2$ equiv). The headspace of the vial was flushed with argon for $1 \mathrm{~min}$. The reaction mixture was stirred at room temperature for $5 \mathrm{~min}$ and then heated at $60{ }^{\circ} \mathrm{C}$ for $20 \mathrm{~h}$ with vigorous stirring. It was cooled, diluted with EtOAc $(50 \mathrm{~mL})$, washed with brine $(3 \times$ $25 \mathrm{~mL}$ ), and dried with $\mathrm{MgSO}_{4}$. The crude mixtures were subjected to the same procedure of dehalogenated byproduct separation as described under general conditions C. The products were purified by column chromatography on silica gel eluting with $0-40 \%$ EtOAc in hexanes. 13-I eluted first.

Characterization Data for Compounds from Table 1. N,N,1-Tris(4-methoxybenzyl)-7-phenyl-1H-imidazo[4,5-c]pyridin-4-amine (14a). General conditions A, $6 \mathrm{~h}, 335 \mathrm{mg}$, 91\%. Yellowish syrup. HRMS (ESI): $m / z[\mathrm{M}+\mathrm{H}]^{+}$calcd for $\mathrm{C}_{36} \mathrm{H}_{35} \mathrm{~N}_{4} \mathrm{O}_{3}$ : 571.27093; found: 571.26842. ${ }^{1} \mathrm{H}$ NMR (400 $\left.\mathrm{MHz}, \mathrm{CDCl}_{3}\right): \delta, 7.78(\mathrm{~s}, 1 \mathrm{H}), 7.68(\mathrm{~s}, 1 \mathrm{H}), 7.36-7.34(\mathrm{~m}$, $3 \mathrm{H}), 7.29-7.27(\mathrm{~d}, J=8.8,4 \mathrm{H}), 7.27-7.25(\mathrm{~m}, 2 \mathrm{H}), 6.87-$ $6.85(\mathrm{~d}, J=8.8,2 \mathrm{H}), 6.71-6.69(\mathrm{~d}, J=8.8,2 \mathrm{H}), 6.56-6.54(\mathrm{~d}$, 
$J=8.8,2 \mathrm{H}), 5.23(\mathrm{~s}, 4 \mathrm{H}), 4.94(\mathrm{~s}, 2 \mathrm{H}), 3.80(\mathrm{~s}, 6 \mathrm{H}), 3.76(\mathrm{~s}$, $3 \mathrm{H})$ ppm. ${ }^{13} \mathrm{C}$ NMR $\left(100 \mathrm{MHz}, \mathrm{CDCl}_{3}\right): \delta, 159.6(\mathrm{Cq}), 158.7$ (Cq), $151.6(\mathrm{Cq}), 141.8,141.0,137.7(\mathrm{Cq}), 136.7(\mathrm{Cq}), 131.6$ (Cq), 130.4, 129.3, 128.2, 128.10, $128.06(\mathrm{Cq}), 128.0(\mathrm{Cq})$, 127.4, 114.1, 113.9, 113.8 (Cq), 55.40, 55.38, $49.64\left(\mathrm{CH}_{2}\right)$, $49.55\left(\mathrm{CH}_{2}\right)$ ppm.

(E)-N,N,1-Tris(4-methoxybenzyl)-7-styryl-1H-imidazo[4,5c]pyridin-4-amine (14b). General conditions A, 16 h, $123 \mathrm{mg}$, $79 \%$. General conditions C, $36 \mathrm{~h}, 83 \mathrm{mg}, 53 \%$. Tan solid. HRMS (ESI): $m / z[\mathrm{M}+\mathrm{H}]^{+}$calcd for $\mathrm{C}_{38} \mathrm{H}_{37} \mathrm{~N}_{4} \mathrm{O}_{3}$ : 597.28658; found: 597.28453. ${ }^{1} \mathrm{H}$ NMR (400 $\mathrm{MHz}, \mathrm{CDCl}_{3}$ ): $\delta, 8.10(\mathrm{~s}, 1 \mathrm{H}) .7 .69(\mathrm{~s}, 1 \mathrm{H}), 7.32-7.23(\mathrm{~m}, 8 \mathrm{H}), 7.20-7.16(\mathrm{~d}$, $J=15.6,1 \mathrm{H}), 7.06-7.04(\mathrm{~d}, J=8.8,2 \mathrm{H}), 6.92-6.89(\mathrm{~d}, J=8.8$, $2 \mathrm{H}), 6.86-6.82(\mathrm{~m}, 5 \mathrm{H}), 5.46(\mathrm{~s}, 2 \mathrm{H}), 5.22(\mathrm{~s}, 4 \mathrm{H}), 3.804(\mathrm{~s}$, $3 \mathrm{H}), 3.796(\mathrm{~s}, 6 \mathrm{H}) \mathrm{ppm} .{ }^{13} \mathrm{C} \mathrm{NMR}\left(100 \mathrm{MHz}, \mathrm{CDCl}_{3}\right): \delta$, $159.6(\mathrm{Cq}), 158.7(\mathrm{Cq}), 151.7(\mathrm{Cq}), 141.0,139.6,138.1(\mathrm{Cq})$, $137.8(\mathrm{Cq}), 131.5(\mathrm{Cq}), 129.3,129.0,128.8,128.6(\mathrm{Cq}), 127.8$ (Cq), 127.6, 127.4, 126.4, 122.2, 114.7, 113.9, 110.8 (Cq), 55.5, 55.4, $49.8\left(\mathrm{CH}_{2}\right), 49.7\left(\mathrm{CH}_{2}\right)$ ppm.

$\mathrm{N}, \mathrm{N}, 1$-Tris(4-methoxybenzyl)-7-phenethyl-1H-imidazo[4,5-c]pyridin-4-amine (14c). General conditions B, 72 h, 55 $\mathrm{mg}, 35 \%$. General conditions F, $29 \mathrm{~h}, 327 \mathrm{mg}, 77 \%$. Colorless syrup. HRMS (ESI): $m / z[\mathrm{M}+\mathrm{H}]^{+}$calcd for $\mathrm{C}_{38} \mathrm{H}_{39} \mathrm{~N}_{4} \mathrm{O}_{3}$ : 599.30224; found: 599.29971. ${ }^{1} \mathrm{H} \mathrm{NMR}\left(400 \mathrm{MHz}, \mathrm{CDCl}_{3}\right): \delta$, $7.76(\mathrm{~s}, 1 \mathrm{H}), 7.63(\mathrm{~s}, 1 \mathrm{H}), 7.31-7.20(\mathrm{~m}, 3 \mathrm{H}), 7.26-7.24(\mathrm{~d}, J$ $=8.8,4 \mathrm{H}), 7.10-7.08(\mathrm{~d}, J=8.8,4 \mathrm{H}), 6.94-6.92(\mathrm{~d}, J=8.8$, $2 \mathrm{H}), 6.87-6.84(\mathrm{~m}, 2 \mathrm{H}), 6.86-6.83(\mathrm{~d}, J=8.8,2 \mathrm{H}), 5.34(\mathrm{~s}$, $2 \mathrm{H}), 5.18$ (s, $4 \mathrm{H}), 3.80(\mathrm{~s}, 6 \mathrm{H}), 3.79(\mathrm{~s}, 3 \mathrm{H}), 3.02-2.88(\mathrm{~m}$, $4 \mathrm{H}) \mathrm{ppm} .{ }^{13} \mathrm{C} \mathrm{NMR}\left(100 \mathrm{MHz}, \mathrm{CDCl}_{3}\right): \delta, 159.6(\mathrm{Cq}), 158.6$ (Cq), $151.4(\mathrm{Cq}), 141.4,141.3(\mathrm{Cq}), 141.0,138.8(\mathrm{Cq}), 131.7$ (Cq), 129.3, 128.59, 128.56 (Cq), 128.48, 127.6, 126.3, 114.7, 113.8, $110.9(\mathrm{Cq}), 55.44,55.36,49.7\left(\mathrm{CH}_{2}\right), 49.4\left(\mathrm{CH}_{2}\right), 38.5$ $\left(\mathrm{CH}_{2}\right), 30.7\left(\mathrm{CH}_{2}\right)$ ppm. For other conditions tested, see Supporting Information.

N,N,1-Tris(4-methoxybenzyl)-1H-imidazo[4,5-c]pyridin-4amine (13-H). General conditions B, $72 \mathrm{~h}, 34 \mathrm{mg}, 30 \%$. Yellowish syrup. HRMS (ESI): $m / z[\mathrm{M}+\mathrm{H}]^{+}$calcd for $\mathrm{C}_{30} \mathrm{H}_{31} \mathrm{~N}_{4} \mathrm{O}_{3}$ : 495.23964; found: 495.23722. ${ }^{1} \mathrm{H}$ NMR (400 $\left.\mathrm{MHz}, \mathrm{CDCl}_{3}\right): \delta, 7.96-7.94(\mathrm{~d}, J=5.6,1 \mathrm{H}), 7.70(\mathrm{~s}, 1 \mathrm{H})$, $7.25-7.23(\mathrm{~d}, J=8.8,4 \mathrm{H}), 7.16-7.14(\mathrm{~d}, J=8.8,2 \mathrm{H}), 6.90-$ $6.87(\mathrm{~d}, J=8.8,2 \mathrm{H}), 6.84-6.82(\mathrm{~d}, J=8.8,4 \mathrm{H}), 6.64-6.62(\mathrm{~d}$, $J=5.6,1 \mathrm{H}), 5.21(\mathrm{~s}, 2 \mathrm{H}), 5.17(\mathrm{~s}, 4 \mathrm{H}), 3.80(\mathrm{~s}, 3 \mathrm{H}), 3.78(\mathrm{~s}$, $6 \mathrm{H})$ ppm. ${ }^{13} \mathrm{C} \mathrm{NMR}\left(100 \mathrm{MHz}, \mathrm{CDCl}_{3}\right): \delta, 159.8(\mathrm{Cq}), 158.6$ (Cq), $152.3(\mathrm{Cq}), 141.1,140.5$ (Cq), 139.2, $131.5(\mathrm{Cq}), 129.2$, 129.0, 127.9 (Cq), 127.3 (Cq), 114.6, 113.9, 96.2, 55.45, 55.36, $49.4\left(\mathrm{CH}_{2}\right), 48.6\left(\mathrm{CH}_{2}\right)$ ppm.

7-lodo-N,N, 1-tris(4-methoxybenzyl)-1H-imidazo[4,5-c]pyridin-4-amine (13-I). General conditions C, $36 \mathrm{~h}, 50 \mathrm{mg}$, $31 \%$. General conditions G, $20 \mathrm{~h}, 110 \mathrm{mg}, 36 \%$. Yellowish foam. HRMS (ESI): $m / z[\mathrm{M}+\mathrm{H}]^{+}$calcd for $\mathrm{C}_{30} \mathrm{H}_{30} \mathrm{IN}_{4} \mathrm{O}_{3}$ : 621.13629; found: 621.13419. ${ }^{1} \mathrm{H}$ NMR (400 $\left.\mathrm{MHz} \mathrm{CDCl}_{3}\right)$ : $\delta, 8.17(\mathrm{~s}, 1 \mathrm{H}), 7.62(\mathrm{~s}, 1 \mathrm{H}), 7.23-7.20(\mathrm{~d}, J=8.8,4 \mathrm{H}), 7.08-$ $7.06(\mathrm{~d}, J=8.8,2 \mathrm{H}), 6.90-6.88(\mathrm{~d}, J=8.8,2 \mathrm{H}), 6.84-6.82(\mathrm{~d}$, $J=8.8,4 \mathrm{H}), 5.67(\mathrm{~s}, 2 \mathrm{H}), 5.15(\mathrm{~s}, 4 \mathrm{H}), 3.80(\mathrm{~s}, 3 \mathrm{H}), 3.79$ (s, $6 \mathrm{H}) \mathrm{ppm} .{ }^{13} \mathrm{C}$ NMR $\left(100 \mathrm{MHz}, \mathrm{CDCl}_{3}\right): \delta, 159.6(\mathrm{Cq}), 158.7$ (Cq), $152.3(\mathrm{Cq}), 149.2,141.4,138.5(\mathrm{Cq}), 131.2(\mathrm{Cq}), 129.8$ (Cq), 129.2, 128.5, $128.4(\mathrm{Cq}), 114.5,113.9,56.0(\mathrm{Cq}), 55.44$, 55.38, $49.8\left(\mathrm{CH}_{2}\right), 48.5\left(\mathrm{CH}_{2}\right)$ ppm.

7-Ethyl-N,N, 1-tris(4-methoxybenzyl)-1H-imidazo[4,5-c]pyridin-4-amine (14d). General conditions B, $72 \mathrm{~h}, 284 \mathrm{mg}$, $31 \%$. General conditions F, $25 \mathrm{~h}, 69 \mathrm{mg}, 76 \%$. Colorless syrup. HRMS (ESI): $m / z[\mathrm{M}+\mathrm{H}]^{+}$calcd for $\mathrm{C}_{32} \mathrm{H}_{35} \mathrm{~N}_{4} \mathrm{O}_{3}$ : 523.27093; found: 523.26894. ${ }^{1} \mathrm{H}$ NMR (400 $\mathrm{MHz} \mathrm{CDCl}_{3}$ ): $\delta, 7.73(\mathrm{~s}, 1 \mathrm{H}), 7.64(\mathrm{~s}, 1 \mathrm{H}), 7.24-7.21(\mathrm{~d}, J=8.8,4 \mathrm{H}), 6.99-$ $6.97(\mathrm{~d}, J=8.8,2 \mathrm{H}), 6.88-6.86(\mathrm{~d}, J=8.8,2 \mathrm{H}), 6.83-6.81(\mathrm{~d}$, $J=8.8,4 \mathrm{H}), 5.44(\mathrm{~s}, 2 \mathrm{H}), 5.15(\mathrm{~s}, 4 \mathrm{H}), 3.79(\mathrm{~s}, 3 \mathrm{H}), 3.78(\mathrm{~s}$, $6 \mathrm{H}), 2.77-2.71(\mathrm{q}, J=7.6,2 \mathrm{H}), 1.25-1.21(\mathrm{t}, J=7.6,3 \mathrm{H})$ ppm. ${ }^{13} \mathrm{C} \mathrm{NMR}\left(100 \mathrm{MHz}, \mathrm{CDCl}_{3}\right): \delta, 159.6(\mathrm{Cq}), 158.6$ (Cq), $151.3(\mathrm{Cq}), 141.0,140.5,138.8(\mathrm{Cq}), 131.8(\mathrm{Cq}), 129.3$, $128.8(\mathrm{Cq}), 128.6(\mathrm{Cq}), 127.6,114.6,113.8,113.2(\mathrm{Cq}), 55.5$, 55.4, $49.7\left(\mathrm{CH}_{2}\right), 49.6\left(\mathrm{CH}_{2}\right), 22.0\left(\mathrm{CH}_{2}\right), 16.2 \mathrm{ppm}$.

7-Isobutyl-N, N, 1-tris(4-methoxybenzyl)-1H-imidazo[4,5-c]pyridin-4-amine (14e). General conditions B, $72 \mathrm{~h}, 658 \mathrm{mg}$, $29 \%$. General conditions F, $21 \mathrm{~h}, 327 \mathrm{mg}$, 85\%. Yellowish syrup. HRMS (ESI): $m / z[\mathrm{M}+\mathrm{H}]^{+}$calcd for $\mathrm{C}_{34} \mathrm{H}_{39} \mathrm{~N}_{4} \mathrm{O}_{3}$ : 551.30224; found: 551.29987. ${ }^{1} \mathrm{H}$ NMR (400 $\mathrm{MHz} \mathrm{CDCl}_{3}$ ): $\delta, 7.67(\mathrm{~s}, 1 \mathrm{H}), 7.63(\mathrm{~s}, 1 \mathrm{H}), 7.24-7.21(\mathrm{~d}, J=8.8,4 \mathrm{H}), 6.98-$ $6.95(\mathrm{~d}, J=8.8,2 \mathrm{H}), 6.88-6.86(\mathrm{~d}, J=8.8,2 \mathrm{H}), 6.84-6.82(\mathrm{~d}$, $J=8.8,4 \mathrm{H}), 5.40(\mathrm{~s}, 2 \mathrm{H}), 5.15(\mathrm{~s}, 4 \mathrm{H}), 3.79(\mathrm{~s}, 3 \mathrm{H}), 3.78(\mathrm{~s}$, $6 \mathrm{H}), 2.51-2.49$ (d, $J=7.2,2 \mathrm{H}), 1.84-1.74$ (septet, $J=6.4$, $1 \mathrm{H}), 0.95-0.94(\mathrm{~d}, J=6.4,6 \mathrm{H}) \mathrm{ppm} .{ }^{13} \mathrm{C} \mathrm{NMR}(100 \mathrm{MHz}$, $\left.\mathrm{CDCl}_{3}\right): \delta, 159.6(\mathrm{Cq}), 158.6(\mathrm{Cq}), 151.4(\mathrm{Cq}), 142.3,140.9$, $139.0(\mathrm{Cq}), 131.8(\mathrm{Cq}), 129.3,128.8(\mathrm{Cq}), 128.7(\mathrm{Cq}), 127.6$, 114.7, 113.8, $110.6(\mathrm{Cq}), 55.5,55.4,49.6\left(\mathrm{CH}_{2}\right), 49.5\left(\mathrm{CH}_{2}\right)$, $38.2\left(\mathrm{CH}_{2}\right), 30.7,22.4 \mathrm{ppm}$.

Methyl (E)-3-(4-(Bis(4-methoxybenzyl)amino)-1-(4-methoxybenzyl)-1H-imidazo[4,5-c]pyridin-7-yl)acrylate (14f). General conditions C, $36 \mathrm{~h}, 86 \mathrm{mg}, 57 \%$. Yellowish syrup. HRMS (ESI): $m / z[\mathrm{M}+\mathrm{H}]^{+}$calcd for $\mathrm{C}_{34} \mathrm{H}_{35} \mathrm{~N}_{4} \mathrm{O}_{5}$ : 579.26077; found: 579.25862. ${ }^{1} \mathrm{H}$ NMR (400 $\left.\mathrm{MHz} \mathrm{CDCl}_{3}\right)$ : $\delta, 8.23(\mathrm{~s}, 1 \mathrm{H}), 8.05-8.01(\mathrm{~d}, J=15.6,1 \mathrm{H}), 7.69(\mathrm{~s}, 1 \mathrm{H})$, $7.24-7.22$ (d, $J=8.8,4 \mathrm{H}), 7.12-7.09$ (d, $J=8.8,2 \mathrm{H}), 6.90-$ $6.88(\mathrm{~d}, J=8.8,2 \mathrm{H}), 6.85-6.83(\mathrm{~d}, J=8.8,4 \mathrm{H}), 6.26-6.22(\mathrm{~d}$, $J=15.6,1 \mathrm{H}), 5.44(\mathrm{~s}, 2 \mathrm{H}), 5.23(\mathrm{~s}, 4 \mathrm{H}), \quad 3.79-3.78$ (overlapped s, 12H) ppm. ${ }^{13} \mathrm{C}$ NMR $\left(100 \mathrm{MHz}, \mathrm{CDCl}_{3}\right): \delta$, $167.8(\mathrm{Cq}), 159.8(\mathrm{Cq}), 158.8(\mathrm{Cq}), 152.8(\mathrm{Cq}), 141.3,138.8$, $138.0(\mathrm{Cq}), 130.9(\mathrm{Cq}), 129.4,129.2,128.2(\mathrm{Cq}), 127.6(\mathrm{Cq})$, $127.3(\mathrm{Cq}), 114.6,114.5,114.0,107.6(\mathrm{Cq}), 55.41,55.36,51.6$, $50.4\left(\mathrm{CH}_{2}\right), 49.7\left(\mathrm{CH}_{2}\right)$ ppm.

$\mathrm{N}, \mathrm{N}, 1$-Tris(4-methoxybenzyl)-7-(phenylethynyl)- $1 \mathrm{H}$ imidazo[4,5-c]pyridin-4-amine (14g). General conditions D, $20 \mathrm{~h}, 138 \mathrm{mg}, 89 \%$. Brown syrup. HRMS (ESI): $m / z[\mathrm{M}+\mathrm{H}]^{+}$ calcd for $\mathrm{C}_{38} \mathrm{H}_{35} \mathrm{~N}_{4} \mathrm{O}_{3}$ : 595.27093; found: 595.26894. ${ }^{1} \mathrm{H}$ NMR $\left(400 \mathrm{MHz}, \mathrm{CDCl}_{3}\right): \delta, 8.22(\mathrm{~s}, 1 \mathrm{H}), 7.67(\mathrm{~s}, 1 \mathrm{H}), 7.39-7.37$ $(\mathrm{m}, 2 \mathrm{H}), 7.33-7.30(\mathrm{~m}, 3 \mathrm{H}), 7.26-7.24(\mathrm{~d}, J=8.4,2 \mathrm{H}), 7.25-$ $7.23(\mathrm{~d}, J=8.4,4 \mathrm{H}), 6.89-6.87(\mathrm{~d}, J=8.4,2 \mathrm{H}), 6.86-6.84(\mathrm{~d}$, $J=8.4,4 \mathrm{H}), 5.75(\mathrm{~s}, 2 \mathrm{H}), 5.21(\mathrm{~s}, 4 \mathrm{H}), 3.80(\mathrm{~s}, 9 \mathrm{H}) \mathrm{ppm} .{ }^{13} \mathrm{C}$ NMR $\left(100 \mathrm{MHz}, \mathrm{CDCl}_{3}\right): \delta, 159.6(\mathrm{Cq}), 158.8(\mathrm{Cq}), 151.9$ (Cq), 146.7, 140.3, 138.3 (Cq), 131.1, 129.3, 128.9, 128.8 (Cq), 128.5, 128.0, 127.0 (Cq), 123.7 (Cq), 114.5, 113.9, 93.6 (Cq), $85.1(\mathrm{Cq}), 55.44,55.38,49.6\left(\mathrm{CH}_{2}\right), 48.5\left(\mathrm{CH}_{2}\right)$ ppm.

$\mathrm{N}, \mathrm{N}, 1$-Tris(4-methoxybenzyl)-7-methyl-1H-imidazo[4,5-c]pyridin-4-amine (14h). General conditions E, $4 \mathrm{~h}, 115 \mathrm{mg}$, 87\%. Yellow syrup. HRMS (ESI): $m / z[\mathrm{M}+\mathrm{H}]^{+}$calcd for $\mathrm{C}_{31} \mathrm{H}_{33} \mathrm{~N}_{4} \mathrm{O}_{3}$ : 509.25528; found: 509.25341. ${ }^{1} \mathrm{H}$ NMR (400 $\left.\mathrm{MHz}, \mathrm{CDCl}_{3}\right): \delta, 7.66(\mathrm{~s}, 1 \mathrm{H}), 7.65(\mathrm{~s}, 1 \mathrm{H}), 7.24-7.21(\mathrm{~d}, J=$ 8.4, $4 \mathrm{H}$ ), 7.00-6.97 (d, $J=8.4,2 \mathrm{H}), 6.88-6.86$ (d, $J=8.4$, $2 \mathrm{H}), 6.83-6.81(\mathrm{~d}, J=8.4,2 \mathrm{H}), 5.45(\mathrm{~s}, 2 \mathrm{H}), 5.15(\mathrm{~s}, 4 \mathrm{H})$, $3.79(\mathrm{~s}, 3 \mathrm{H}), 3.78(\mathrm{~s}, 6 \mathrm{H}), 2.35(\mathrm{~s}, 3 \mathrm{H}) \mathrm{ppm} .{ }^{13} \mathrm{C}$ NMR $(100$ $\left.\mathrm{MHz}, \mathrm{CDCl}_{3}\right): \delta, 159.5(\mathrm{Cq}), 158.6(\mathrm{Cq}), 151.4(\mathrm{Cq}), 141.5$, 140.8, 139.5 (Cq), 131.8 (Cq), 129.3, 129.0, 128.5 (Cq), 127.5, 114.6, 113.8, 106.6 (Cq), 55.44, 55.36, $49.7\left(\mathrm{CH}_{2}\right), 49.3$ $\left(\mathrm{CH}_{2}\right), 15.1 \mathrm{ppm}$.

7-Benzyl-N,N, 1-tris(4-methoxybenzyl)-1H-imidazo[4,5-c]pyridin-4-amine (14i). General conditions E, 4 h, $69 \mathrm{mg}, 45 \%$. Brown syrup. HRMS (ESI): $m / z[\mathrm{M}+\mathrm{H}]^{+}$calcd for 
$\mathrm{C}_{37} \mathrm{H}_{37} \mathrm{~N}_{4} \mathrm{O}_{3}$ : 585.286588; found: 585.28433. ${ }^{1} \mathrm{H}$ NMR (400 $\left.\mathrm{MHz}, \mathrm{CDCl}_{3}\right): \delta, 7.76(\mathrm{~s}, 1 \mathrm{H}), 7.59(\mathrm{~s}, 1 \mathrm{H}), 7.32-7.23(\mathrm{~m}$, $7 \mathrm{H}), 7.09-7.08(\mathrm{~d}, J=8.8,2 \mathrm{H}), 6.87-6.82(\mathrm{~m}, 8 \mathrm{H}), 5.22(\mathrm{~s}$, $4 \mathrm{H}), 5.05(\mathrm{~s}, 2 \mathrm{H}), 4.00(\mathrm{~s}, 2 \mathrm{H}), 3.80(\mathrm{~s}, 9 \mathrm{H}) \mathrm{ppm} .{ }^{13} \mathrm{C} \mathrm{NMR}$ $\left(100 \mathrm{MHz}, \mathrm{CDCl}_{3}\right): \delta, 159.5(\mathrm{Cq}), 158.6(\mathrm{Cq}), 151.8(\mathrm{Cq})$, $142.9,141.4(\mathrm{Cq}), 140.9,139.2(\mathrm{Cq}), 131.6(\mathrm{Cq}), 129.3,129.0$ (Cq), $128.9(\mathrm{Cq}), 128.8,128.0,127.2,126.5,114.6,113.8$, $108.5(\mathrm{Cq}), 55.42,55.35,49.7\left(\mathrm{CH}_{2}\right), 49.0\left(\mathrm{CH}_{2}\right), 35.0\left(\mathrm{CH}_{2}\right)$ ppm.

7-Isopropyl-N,N, 1-tris(4-methoxybenzyl)-1H-imidazo[4,5c]pyridin-4-amine (14j). General conditions F, $27 \mathrm{~h}, 80 \mathrm{mg}$, $86 \%$. Contains $\sim 20 \%$ of $n$-propyl impurity. Colorless syrup. HRMS (ESI): $m / z[\mathrm{M}+\mathrm{H}]^{+}$calcd for $\mathrm{C}_{33} \mathrm{H}_{37} \mathrm{~N}_{4} \mathrm{O}_{3}$ : 537.28658; found: 537.28573. ${ }^{1} \mathrm{H} \mathrm{NMR}\left(400 \mathrm{MHz}, \mathrm{CDCl}_{3}\right)$ : $\delta, 7.89(\mathrm{~s}, 1 \mathrm{H}), 7.63(\mathrm{~s}, 1 \mathrm{H}), 7.25-7.22(\mathrm{~d}, J=8.8,4 \mathrm{H}), 6.98-$ $6.96(\mathrm{~d}, J=8.8,2 \mathrm{H}), 6.88-6.86(\mathrm{~d}, J=8.8,2 \mathrm{H}), 6.84-6.82(\mathrm{~d}$, $J=8.8,4 \mathrm{H}), 5.44(\mathrm{~s}, 2 \mathrm{H}), 5.16(\mathrm{~s}, 4 \mathrm{H}), 3.79(\mathrm{~s}, 3 \mathrm{H}), 3.78(\mathrm{~s}$, $6 \mathrm{H}$ ), 3.30-3.20 (septet, $J=6.8,1 \mathrm{H}), 1.25-1.24(\mathrm{~d}, J=6.4$, $6 \mathrm{H})$ ppm. ${ }^{13} \mathrm{C}$ NMR (100 MHz, $\mathrm{CDCl}_{3}$ ): $\delta, 159.6(\mathrm{Cq}), 158.6$ $(\mathrm{Cq}), 151.0(\mathrm{Cq}), 141.4,138.1(\mathrm{Cq}), 138.0,131.8(\mathrm{Cq}), 129.3$, $128.7(\mathrm{Cq}), 128.6(\mathrm{Cq}), 127.6,118.3(\mathrm{Cq}), 114.6,113.8,55.45$, 55.36, $50.0\left(\mathrm{CH}_{2}\right), 49.7\left(\mathrm{CH}_{2}\right), 26.3,24.3 \mathrm{ppm}$.

Ethyl 4-(4-(Bis(4-methoxybenzyl)amino)-1-(4-methoxybenzyl)-1H-imidazo[4,5-c]pyridin-7-yl)butanoate (14k). General conditions G, $20 \mathrm{~h}, 100 \mathrm{mg}, 32 \%$. Colorless syrup. HRMS (ESI): $m / z[\mathrm{M}+\mathrm{H}]^{+}$calcd for $\mathrm{C}_{36} \mathrm{H}_{41} \mathrm{~N}_{4} \mathrm{O}_{5}$ : 609.30773; found: 609.30580. ${ }^{1} \mathrm{H}$ NMR $\left(400 \mathrm{MHz}, \mathrm{CDCl}_{3}\right): \delta, 7.69$ (s, 1H), 7.65 $(\mathrm{s}, 1 \mathrm{H}), 7.24-7.22(\mathrm{~d}, J=8.8,4 \mathrm{H}), 6.98-6.96(\mathrm{~d}, J=8.8,2 \mathrm{H})$, 6.87-6.85 (d, $J=8.8,2 \mathrm{H}), 6.84-6.82(\mathrm{~d}, J=8.8,4 \mathrm{H}), 5.47$ ( , $2 \mathrm{H}), 5.16(\mathrm{~s}, 4 \mathrm{H}), 4.14-4.08(\mathrm{q}, J=7.2,2 \mathrm{H}), 3.78$ (overlapped $\mathrm{s}, 9 \mathrm{H}), 2.71-2.68(\mathrm{~m}, 2 \mathrm{H}), 2.37-2.33(\mathrm{t}, J=7.2,2 \mathrm{H}), 1.91-$ $1.86(\mathrm{~m}, 2 \mathrm{H}), 1.26-1.22(\mathrm{t}, J=7.2,3 \mathrm{H}) \mathrm{ppm} .{ }^{13} \mathrm{C} \mathrm{NMR}(100$ $\left.\mathrm{MHz}, \mathrm{CDCl}_{3}\right): \delta, 173.5(\mathrm{Cq}), 159.5(\mathrm{Cq}), 158.6(\mathrm{Cq}), 151.4$ (Cq), 141.6, 141.1, $138.7(\mathrm{Cq}), 131.7(\mathrm{Cq}), 129.3,128.8(\mathrm{Cq})$, $128.7(\mathrm{Cq}), 127.5,114.6,113.8,110.6(\mathrm{Cq}), 60.5\left(\mathrm{CH}_{2}\right), 55.42$, 55.36, $49.6\left(\mathrm{CH}_{2}\right), 49.4\left(\mathrm{CH}_{2}\right), 33.7\left(\mathrm{CH}_{2}\right), 28.4\left(\mathrm{CH}_{2}\right), 27.4$ $\left(\mathrm{CH}_{2}\right), 14.4 \mathrm{ppm}$.

Synthesis of Phosphoramidites 20i, 20d, and 20e and Attempted Synthesis of 20a. 7-Benzyl-1H-imidazo[4,5c]pyridin-4-amine, Trifluoroacetic Acid (TFA) Salt (15i). This compound was synthesized according to the modified general procedure. $^{52}$ A solution of $14 \mathbf{i}(589 \mathrm{mg}, 1 \mathrm{mmol})$ in TFA (6 $\mathrm{mL}$ ) was placed in a $100 \mathrm{~mL}$ pressure tube, anisole $(0.65 \mathrm{~mL}, 6$ equiv) was added, and the mixture was heated at $70{ }^{\circ} \mathrm{C}$ for $24 \mathrm{~h}$ with vigorous stirring. It was cooled and concentrated under reduced pressure. The residue was coevaporated with toluene $(3 \times 25 \mathrm{~mL})$ to obtain $15 \mathrm{i}$ (ca. $0.34 \mathrm{~g}$, quantitative) as an oil that was taken into next step without further purification.

1-(7-Benzyl-1H-imidazo[4,5-c]pyridin-4-yl)-3,3,4,4-tetramethylpyrrolidine-2,5-dione (16i). This compound was synthesized according to the reported general procedure. ${ }^{53} \mathrm{~A}$ solution of $15 \mathrm{i}(0.34 \mathrm{~g}, 1 \mathrm{mmol})$ in pyridine $(10 \mathrm{~mL})$ was placed in a $100 \mathrm{~mL}$ Schlenk flask. Tetramethylsuccinic anhydride $\left(\mathrm{M}_{4} \mathrm{SA}\right)^{59}(0.312 \mathrm{~g}, 2 \mathrm{mmol})$ and DBU $(0.6 \mathrm{~mL}, 4$ $\mathrm{mmol}$ ) were added, and the mixture was heated at $120{ }^{\circ} \mathrm{C}$ under argon for $20 \mathrm{~h}$ with vigorous stirring. It was cooled and concentrated under reduced pressure. The residue was coevaporated with toluene $(3 \times 25 \mathrm{~mL})$. The product was purified by column chromatography on silica gel eluting with $0-5 \% \mathrm{MeOH}$ in $\mathrm{CH}_{2} \mathrm{Cl}_{2}$ to give a cream foam. It was taken in $\mathrm{SOCl}_{2}(10 \mathrm{~mL})$, heated at $80{ }^{\circ} \mathrm{C}$ for $2 \mathrm{~h}$, cooled and concentrated under reduced pressure. The residue was coevaporated with EtOAc $(3 \times 25 \mathrm{~mL})$. The product was purified by column chromatography on silica gel eluting with $0-5 \% \mathrm{MeOH}$ in $\mathrm{CH}_{2} \mathrm{Cl}_{2}$ to give $\mathbf{1 6} \mathbf{i}$ as a cream foam in $57 \%$ yield (0.208 g). HRMS (ESI): $m / z[\mathrm{M}+\mathrm{H}]^{+}$calcd for $\mathrm{C}_{21} \mathrm{H}_{23} \mathrm{~N}_{4} \mathrm{O}_{2}$ : 363.18212; found: 363.18045. ${ }^{1} \mathrm{H}$ NMR (400 $\left.\mathrm{MHz}, \mathrm{CD}_{3} \mathrm{OD}\right): \delta, 8.36(\mathrm{~s}, 1 \mathrm{H}), 8.12(\mathrm{~s}, 1 \mathrm{H}), 7.29-7.20(\mathrm{~m}$, $5 \mathrm{H}), 4.35$ (s, 2H), 1.37 (bs, 12H) ppm. ${ }^{13} \mathrm{C}$ NMR (100 MHz, $\left.\mathrm{CD}_{3} \mathrm{OD}\right): \delta, 183.4,146.2,141.8,139.7,137.5,129.8,127.7$, 124.7, 118.3, 35.5, $21.8 \mathrm{ppm}$.

(2R,3S,5R)-5-(7-Benzyl-4-(3,3,4,4-tetramethyl-2,5-dioxopyrrolidin-1-yl)-1H-imidazo[4,5-c]pyridin-1-yl)-2-(((4methylbenzoyl)oxy)methyl)tetrahydrofuran-3-yl 4-Methylbenzoate (17i). This compound was synthesized according to the reported general procedure. ${ }^{53}$ To a solution of $16 \mathbf{i}(0.19$ g, $0.52 \mathrm{mmol})$ in dry $\mathrm{CH}_{3} \mathrm{CN}(25 \mathrm{~mL})$ in a $100 \mathrm{~mL}$ roundbottom flask, $60 \% \mathrm{NaH}$ in oil $(42 \mathrm{mg}, 1.05 \mathrm{mmol})$ was added, and the mixture was vigorously stirred at room temperature under argon for $45 \mathrm{~min}$. 1-( $\alpha)$-Chloro-3,5-di-O-( $p$-toluoyl)-2deoxy-D-ribose $(0.368 \mathrm{~g}, 0.94 \mathrm{mmol})$ was subsequently added in one portion, and the stirring was continued at room temperature for $4.5 \mathrm{~h}$. The mixture was filtered through Celite and concentrated. The product was purified by column chromatography on silica gel eluting with 50\% EtOAc in hexanes. Compound $\mathbf{1 7} \mathbf{i}$ was obtained as a yellowish syrup in $39 \%$ yield $(0.145 \mathrm{~g})$. HRMS (ESI): $m / z[\mathrm{M}+\mathrm{H}]^{+}$calcd for $\mathrm{C}_{42} \mathrm{H}_{43} \mathrm{~N}_{4} \mathrm{O}_{7}$ : 715.31322; found: 715.31184. ${ }^{1} \mathrm{H}$ NMR (400 $\left.\mathrm{MHz}, \mathrm{CDCl}_{3}\right): \delta, 8.32(\mathrm{~s}, 1 \mathrm{H}), 8.19(\mathrm{~s}, 1 \mathrm{H}), 7.92-7.90(\mathrm{~d}, J=$ $8.4,2 \mathrm{H}), 7.87-7.85(\mathrm{~d}, J=8.4,2 \mathrm{H}), 7.34-7.32(\mathrm{~d}, J=8.4$, $2 \mathrm{H}), 7.92-7.90(\mathrm{~d}, J=8.4,2 \mathrm{H}), 7.14-7.11(\mathrm{~m}, 3 \mathrm{H}), 7.06-$ $7.04(\mathrm{~m}, 2 \mathrm{H}), 6.20-6.17\left(\mathrm{dd}, J_{1}=5.2, J_{2}=9.2,1 \mathrm{H}\right), 5.54-5.53$ $(\mathrm{m}, 1 \mathrm{H}), 4.60-4.49(\mathrm{~m}, 4 \mathrm{H}), 4.38-4.34(\mathrm{AB} / 2, J=16.8,1 \mathrm{H})$, $2.49(\mathrm{~s}, 3 \mathrm{H}), 2.46-2.42(\mathrm{~m}, 1 \mathrm{H}), 2.40(\mathrm{~s}, 3 \mathrm{H}), 2.06-2.01(\mathrm{~m}$, 1H), 1.39 (bs, $1 \mathrm{H})$ ppm. ${ }^{13} \mathrm{C}$ NMR (100 MHz, $\left.\mathrm{CDCl}_{3}\right): \delta$, $181.6(\mathrm{Cq}), 166.2(\mathrm{Cq}), 165.8(\mathrm{Cq}), 144.8(\mathrm{Cq}), 144.6,144.4$ $(\mathrm{Cq}), 142.3,139.6(\mathrm{Cq}), 138.7(\mathrm{Cq}), 138.6(\mathrm{Cq}), 137.5(\mathrm{Cq})$, 130.0, 129.8, 129.54, 129.47, 129.2, 128.1, 127.1, 126.6 (Cq), $126.5(\mathrm{Cq}), 120.0(\mathrm{Cq}), 85.8,82.7,74.8,64.3\left(\mathrm{CH}_{2}\right), 48.1$ (Cq), $39.4\left(\mathrm{CH}_{2}\right), 35.8\left(\mathrm{CH}_{2}\right), 21.9,21.8,21.7,21.5$ ppm. For the critical NOESY correlations, see Figure $\mathrm{S} 1$ and copies of spectra (Supporting Information).

1-(7-Benzyl-1-((2R,4S,5R)-4-hydroxy-5-(hydroxylmethyl)tetrahydrofuran-2-yl)-1H-imidazo[4,5-c]pyridin-4-yl)-3,3,4,4tetramethylpyrrolidine-2,5-dione (18i). This compound was synthesized according to the general procedure. ${ }^{53}$ To a solution of $17 \mathbf{i}(0.14 \mathrm{~g}, 0.20 \mathrm{mmol})$ in dry $\mathrm{MeOH}(4 \mathrm{~mL})$ in a $25 \mathrm{~mL}$ round-bottom flask, $\mathrm{NaOMe}(32 \mathrm{mg}, 0.60 \mathrm{mmol})$ was added. The mixture was stirred at room temperature under argon for 2 $\mathrm{h}$ and concentrated in vacuo. The product was purified by column chromatography on silica gel eluting with $0-10 \%$ $\mathrm{MeOH}$ in dichloromethane to obtain $\mathbf{1 8} \mathbf{i}$ as an off-white solid in $66 \%$ yield $(62 \mathrm{mg})$. HRMS (ESI): $m / z[\mathrm{M}+\mathrm{H}]^{+}$calcd for $\mathrm{C}_{26} \mathrm{H}_{31} \mathrm{~N}_{4} \mathrm{O}_{5}$ : 479.22948; found: 479.22931. ${ }^{1} \mathrm{H}$ NMR (400 $\left.\mathrm{MHz}, \mathrm{CD}_{3} \mathrm{OD}\right): \delta, 8.69$ (s, $\left.1 \mathrm{H}\right), 8.14(\mathrm{~s}, 1 \mathrm{H}), 7.32-7.14(\mathrm{~m}$, $5 \mathrm{H}), 6.35-6.32\left(\mathrm{dd}, J_{1}=6.4, J_{2}=12.8,1 \mathrm{H}\right), 4.61-4.57(\mathrm{AB} / 2$, $J=16.8,1 \mathrm{H}), 4.47-4.30(\mathrm{AB} / 2, J=16.8,1 \mathrm{H}), 4.46-4.44(\mathrm{~m}$, $1 \mathrm{H}), 3.95-3.92($ app q, $J=3.6,1 \mathrm{H}), 3.73-3.69\left(\right.$ app dd, $J_{1}=$ 3.6, $\left.J_{2}=12.0,1 \mathrm{H}\right), 3.66-3.62\left(\operatorname{app~dd}, J_{1}=3.6, J_{2}=12.0,1 \mathrm{H}\right)$, $2.52-2.46\left(\mathrm{ddd}, J_{1}=J_{2}=6.0, J_{3}=12.8,1 \mathrm{H}\right), 2.14-2.08\left(\mathrm{ddd}, J_{1}\right.$ $\left.=4.4, J_{2}=6.0, J_{3}=10.4,1 \mathrm{H}\right), 1.37(\mathrm{bs}, 12 \mathrm{H}) \mathrm{ppm} .{ }^{13} \mathrm{C} \mathrm{NMR}$ $\left(100 \mathrm{MHz}, \mathrm{CD}_{3} \mathrm{OD}\right): \delta, 183.4(\mathrm{Cq}), 145.9(\mathrm{Cq}), 144.3,141.0$ $(\mathrm{Cq}), 140.1(\mathrm{Cq}), 138.6(\mathrm{Cq}), 138.4(\mathrm{Cq}), 130.1,129.5,127.9$, $123.5(\mathrm{Cq}), 89.2,87.1,71.7,62.6\left(\mathrm{CH}_{2}\right), 48.9(\mathrm{Cq}), 42.0$ $\left(\mathrm{CH}_{2}\right), 35.9\left(\mathrm{CH}_{2}\right), 21.88,21.84$ ppm. 
1-(7-Benzyl-1-((2R,4S,5R)-5-((bis(4-methoxyphenyl)(phenyl)methoxy)methyl)-4-hydroxytetrahydrofuran-2-yl)$1 \mathrm{H}$-imidazo[4,5-c]pyridin-4-yl)-3,3,4,4-tetramethylpyrrolidine-2,5-dione (19i). This compound was synthesized according to the reported general procedure. ${ }^{53}$ To a solution of $18 \mathrm{i}$ (56 mg, $0.12 \mathrm{mmol}$ ) in pyridine $(2 \mathrm{~mL}), 4,4^{\prime}$ dimethoxytrityl chloride (DMT-Cl) (155 mg, $0.457 \mathrm{mmol}$ ) was added in one portion, and the mixture was stirred at room temperature under argon for $5 \mathrm{~h}$ (TLC showed complete conversion). $\mathrm{MeOH}(0.2 \mathrm{~mL})$ was then added, and the mixture was concentrated in vacuo. The product was purified by column chromatography on silica gel (neutralized with triethylamine) eluting with 5-20\% acetone in dichloromethane to obtain $19 \mathrm{i}$ as a colorless solid in $69 \%$ yield $(63 \mathrm{mg})$. HRMS (ESI): $m / z[\mathrm{M}+\mathrm{H}]^{+}$calcd for $\mathrm{C}_{47} \mathrm{H}_{49} \mathrm{~N}_{4} \mathrm{O}_{7}: 781.36017$; found: 781.35738. ${ }^{1} \mathrm{H}$ NMR $\left(400 \mathrm{MHz}, \mathrm{CDCl}_{3}\right): \delta, 8.24(\mathrm{~s}, 1 \mathrm{H}), 8.10$ $(\mathrm{s}, 1 \mathrm{H}), 7.38-7.10(\mathrm{~m}, 14 \mathrm{H}), 6.82-6.80(\mathrm{~d}, J=8.4,4 \mathrm{H})$, 6.16-6.12 (dd, $\left.J_{1}=6.4, J_{2}=12.4,1 \mathrm{H}\right), 4.50-4.46(\mathrm{AB} / 2, J=$ $16.8,1 \mathrm{H}), 4.43-4.38(\mathrm{~m}, 1 \mathrm{H}), 4.36-4.32(\mathrm{AB} / 2, J=16.8,1 \mathrm{H})$, 4.01-3.98 (app q, $J=4.4,1 \mathrm{H}), 3.78(\mathrm{~s}, 6 \mathrm{H}), 3.36-3.32$ (app dd, $\left.J_{1}=4.4, J_{2}=10.4,1 \mathrm{H}\right), 3.28-3.24\left(\mathrm{app} d \mathrm{~d}, J_{1}=4.8, J_{2}=\right.$ $10.4,1 \mathrm{H}), 2.6$ (bs, $1 \mathrm{H}), 2.28-2.22\left(\mathrm{ddd}, J_{1}=J_{2}=6.0, J_{3}=13.2\right.$, $1 \mathrm{H}), 1.90-1.84$ (ddd, $\left.J_{1}=J_{2}=5.6, J_{3}=9.6,1 \mathrm{H}\right), 1.39-1.38$ (overlapped s, $12 \mathrm{H}$ ) ppm. $\left.{ }^{13} \mathrm{C} \mathrm{NMR} \mathrm{(100} \mathrm{MHz} \mathrm{CDCl}_{3}\right): \delta$, 181.7 (Cq), 158.7 (Cq), 144.5 (Cq), 144.1, 142.6, 139.4 (Cq), $138.8(\mathrm{Cq}), 138.2(\mathrm{Cq}), 137.6(\mathrm{Cq}), 135.63(\mathrm{Cq}), 135.55$ (Cq), 130.12, 130.09, 129.1, 128.6, 128.13, 128.10, 127.11, 127.07, $120.6(\mathrm{Cq}), 113.4,86.8(\mathrm{Cq}), 85.7,85.2,72.0,63.7$ $\left(\mathrm{CH}_{2}\right)$, 55.3, $48.0(\mathrm{Cq}), 41.4\left(\mathrm{CH}_{2}\right), 35.6\left(\mathrm{CH}_{2}\right), 21.8,21.4$ ppm.

(2R,3S,5R)-5-(7-Benzyl-4-(3,3,4,4-tetramethyl-2,5-dioxopyrrolidin-1-yl)-1H-imidazo[4,5-c]pyridin-1-yl)-2-((bis(4methoxyphenyl)(phenyl)methoxy)methyl)tetrahydrofuran3-yl (2-Cyanoethyl) Diisopropylphosphoramidite (20i). This compound was synthesized according to the reported general procedure. $^{60}$ To a solution of $19 \mathrm{i}(62 \mathrm{mg}, 0.080 \mathrm{mmol})$ in dry $\mathrm{CH}_{2} \mathrm{Cl}_{2}(2 \mathrm{~mL})$ containing $\mathrm{N}, \mathrm{N}$-diisopropylethylamine (DIEA) (70 $\mu \mathrm{L}, 0.4 \mathrm{mmol}$ ), 2-cyanoethyl- $N, N$-diisopropyl chlorophosphoramidite $(40 \mu \mathrm{L}, 0.175 \mathrm{mmol})$ was added in one portion, and the mixture was stirred at room temperature under argon for $3 \mathrm{~h}$ (TLC showed complete conversion). The mixture was concentrated in vacuo at rt, and the product was purified by column chromatography on silica gel (neutralized with triethylamine) eluting with $50 \%$ EtOAc in hexanes containing $1 \%$ triethylamine, to obtain $20 \mathrm{i}$ as a mixture of diastereomers (colorless solid, $R_{f} \sim 0.5$ in $5 \%$ acetone $/ \mathrm{CH}_{2} \mathrm{Cl}_{2}$, two close spots visible on TLC) in $49 \%$ yield ( $38 \mathrm{mg}$ ). HRMS (ESI): $\mathrm{m} / z$ $[\mathrm{M}+\mathrm{H}]^{+}$calcd for $\mathrm{C}_{56} \mathrm{H}_{66} \mathrm{~N}_{6} \mathrm{O}_{8} \mathrm{P}$ : 981.46801; found: 981.46481. ${ }^{1} \mathrm{H}$ NMR (400 MHz, acetone- $\left.d_{6}\right): \delta, 8.40,8.39(\mathrm{~s}$, $1 \mathrm{H}), 8.21,8.19(\mathrm{~s}, 1 \mathrm{H}), 7.45-7.18(\mathrm{~m}, 14 \mathrm{H}), 6.84-6.80(\mathrm{~m}$, $4 \mathrm{H}), 6.40-6.35\left(\mathrm{dd}, J_{1}=7.0, J_{2}=12.8,1 \mathrm{H}\right), 4.68-4.78(\mathrm{~m}$, $2 \mathrm{H}), 4.56-4.52,4.53-4.49(\mathrm{AB} / 2, J=16.4,1 \mathrm{H}), 4.28-4.26$, $4.24-4.21($ app q, $J=4.4,1 \mathrm{H}), 3.763,3.757(\mathrm{~s}, 6 \mathrm{H}), 3.67-3.58$ (m, 2H), 3.36-3.32 (m, 2H), 2.91-2.78 (m, 3H), 2.76-2.73 $(\mathrm{t}, J=6.0,1 \mathrm{H}), 2.68-2.65(\mathrm{t}, J=6.0,1 \mathrm{H}), 1.35,1.31(\mathrm{bs}, 12 \mathrm{H})$, $1.21-1.19(\mathrm{~m}, 6 \mathrm{H}), 1.15-1.14,1.13-1.11(\mathrm{~d}, J=6.8,6 \mathrm{H})$ ppm. ${ }^{13} \mathrm{C}$ NMR $\left(100 \mathrm{MHz}\right.$, acetone- $\left.d_{6}\right): \delta, 181.7,159.6,145.9$, $144.36,144.27,144.02,143.97,140.4,140.08,140.05,139.2$, $138.8,136.64,136.58,136.52,130.96,130.93,129.7,129.34$, $129.31,128.97,128.91,128.6,127.6,127.50,127.47,122.3$, $122.2,119.0,114.0,87.22,87.18,86.6,86.4,86.3,86.2,74.4$, 74.0, 73.8, 64.3, 64.3, 59.7, 59.6, 59.4, 55.5, 55.0, 48.3, 44.06, $43.99,43.94,43.86,40.4,40.3,35.5,24.94,24.86,24.82,22.0$,
21.7, 21.4, 20.8, 20.7 ppm. ${ }^{31} \mathrm{P}$ NMR (162 MHz, acetone- $\left.d_{6}\right): \delta$, $149.8,149.6 \mathrm{ppm}$.

7-Ethyl-1H-imidazo[4,5-c]pyridin-4-amine, Trifluoroacetic Acid Salt (15d). This compound was synthesized in a similar fashion to $\mathbf{1 5 i}$. A solution of $\mathbf{1 4 d}(750 \mathrm{mg}, 1.4 \mathrm{mmol})$ in TFA $(10 \mathrm{~mL})$ was placed in a $100 \mathrm{~mL}$ pressure tube, anisole (ca. 1 $\mathrm{mL}, 6$ equiv) was added, and the mixture was heated at $70{ }^{\circ} \mathrm{C}$ for $24 \mathrm{~h}$ with vigorous stirring. It was cooled and concentrated under reduced pressure. The residue was coevaporated with toluene $(3 \times 20 \mathrm{~mL})$ to obtain $15 \mathrm{~d}$ (ca. $0.4 \mathrm{~g}$, quantitative) as an oil that was taken into next step without further purification.

1-(7-Ethyl-1H-imidazo[4,5-c]pyridin-4-yl)-3,3,4,4-tetramethylpyrrolidine-2,5-dione (16d). This compound was synthesized in a similar fashion to $16 \mathbf{i}$. A solution of $15 \mathrm{~d}(0.4 \mathrm{~g}, 1.4$ $\mathrm{mmol})$ in pyridine $(15 \mathrm{~mL})$ was placed in a $100 \mathrm{~mL}$ Schlenk flask. Tetramethylsuccinic anhydride $\left(\mathrm{M}_{4} \mathrm{SA}\right)(0.5 \mathrm{~g}, 3.2 \mathrm{mmol})$ and DBU ( $1 \mathrm{~mL}, 6.7 \mathrm{mmol})$ were added, and the mixture was heated at $120{ }^{\circ} \mathrm{C}$ under argon for $22 \mathrm{~h}$ with vigorous stirring. It was cooled and concentrated under reduced pressure. The residue was coevaporated with toluene $(3 \times 20 \mathrm{~mL})$. The product was purified by column chromatography on silica gel eluting with $0-5 \% \mathrm{MeOH}$ in $\mathrm{CH}_{2} \mathrm{Cl}_{2}$ to give a cream solid. It was taken in $\mathrm{SOCl}_{2}(12 \mathrm{~mL})$, heated at $80{ }^{\circ} \mathrm{C}$ for $2 \mathrm{~h}$, cooled, and concentrated under reduced pressure. The residue was coevaporated with EtOAc $(3 \times 20 \mathrm{~mL})$. The product was purified by column chromatography on silica gel eluting with $0-8 \% \mathrm{MeOH}$ in $\mathrm{CH}_{2} \mathrm{Cl}_{2}$ to give $16 \mathrm{~d}$ as a cream solid in $88 \%$ yield $(0.37 \mathrm{~g})$. HRMS (ESI): $m / z[\mathrm{M}+\mathrm{H}]^{+}$calcd for $\mathrm{C}_{16} \mathrm{H}_{21} \mathrm{~N}_{4} \mathrm{O}_{2}$ : 301.16647; found: 301.16501. ${ }^{1} \mathrm{H}$ NMR (400 $\left.\mathrm{MHz}, \mathrm{CD}_{3} \mathrm{OD}\right): \delta, 8.52(\mathrm{~s}, 1 \mathrm{H}), 8.24(\mathrm{~s}, 1 \mathrm{H}), 3.07-3.01(\mathrm{q}, J=$ $7.2,2 \mathrm{H}), 1.41-1.37(\mathrm{t}, J=7.2,3 \mathrm{H}), 1.37$ (bs, $12 \mathrm{H}) \mathrm{ppm} .{ }^{13} \mathrm{C}$ NMR (100 MHz, CD 3 OD): $\delta, 182.9,146.9,143.5,139.6$, $135.4,135.1,128.7,48.9,23.2,21.8,14.5 \mathrm{ppm}$.

(2R,3S,5R)-5-(7-Ethyl-4-(3,3,4,4-tetramethyl-2,5-dioxopyrrolidin-1-yl)- $1 \mathrm{H}$-imidazo[4,5-c]pyridin-1-yl)-2-(((4methylbenzoyl)oxy)methyl)tetrahydrofuran-3-yl 4-Methylbenzoate $(17 d)$. This compound was synthesized in a similar fashion to $17 \mathbf{i}$. To a solution of $16 \mathbf{i}(0.35 \mathrm{~g}, 1.17 \mathrm{mmol})$ in dry $\mathrm{CH}_{3} \mathrm{CN}(60 \mathrm{~mL})$ in a $250 \mathrm{~mL}$ round-bottom flask, $60 \% \mathrm{NaH}$ in oil (100 mg, $2.5 \mathrm{mmol}$ ) was added, and the mixture was vigorously stirred at room temperature under argon for $45 \mathrm{~min}$. 1- $(\alpha)$-Chloro-3,5-di-O-( $p$-toluoyl)-2-deoxy-D-ribose $(0.817 \mathrm{~g}$, $2.1 \mathrm{mmol})$ was subsequently added portionwise over $1 \mathrm{~h}$, and the stirring was continued at room temperature for overall $5 \mathrm{~h}$. The mixture was filtered through Celite and concentrated. The product was purified by column chromatography on silica gel eluting with $0-50 \%$ EtOAc in hexanes and concentrated repeatedly with dichloromethane. Compound $17 \mathrm{~d}$ was obtained as a yellowish syrup in $65 \%$ yield $(0.494 \mathrm{~g})$. HRMS (ESI): $m / z[\mathrm{M}+\mathrm{H}]^{+}$calcd for $\mathrm{C}_{37} \mathrm{H}_{41} \mathrm{~N}_{4} \mathrm{O}_{7}$ : 653.29757; found: 653.29654. ${ }^{1} \mathrm{H}$ NMR (400 MHz, $\mathrm{CDCl}_{3}$ ): $\delta, 8.27$ (s, $\left.1 \mathrm{H}\right), 8.25$ $(\mathrm{s}, 1 \mathrm{H}), 7.92-7.90(\mathrm{~d}, J=8.0,2 \mathrm{H}), 7.88-7.86(\mathrm{~d}, J=8.0,2 \mathrm{H})$, $7.30-7.28(\mathrm{~d}, J=8.4,2 \mathrm{H}), 7.24-7.22(\mathrm{~d}, J=8.4,2 \mathrm{H}), 6.60-$ $6.57\left(\mathrm{dd}, J_{1}=6.4, J_{2}=12.8,1 \mathrm{H}\right), 5.72-5.68(\mathrm{~m}, 1 \mathrm{H}), 4.67-$ $4.59(\mathrm{~m}, 3 \mathrm{H}), 3.16-3.00(\mathrm{~m}, 2 \mathrm{H}), 2.82-2.79\left(\mathrm{dd}, J_{1}=4.4, J_{2}=\right.$ $6.8,2 \mathrm{H}), 2.44(\mathrm{~s}, 3 \mathrm{H}), 2.40(\mathrm{~s}, 3 \mathrm{H}), 1.43-1.40(\mathrm{t}, J=7.6,3 \mathrm{H})$, 1.37 (bs, 1H) ppm. ${ }^{13} \mathrm{C}$ NMR $\left(100 \mathrm{MHz}, \mathrm{CDCl}_{3}\right): \delta, 181.7$ (Cq), $166.3(\mathrm{Cq}), 165.9(\mathrm{Cq}), 144.9(\mathrm{Cq}), 144.4(\mathrm{Cq}), 142.6$, 142.0, 138.9 (Cq), 137.6 (Cq), 137.3 (Cq), 130.0, 129.9, 129.8, 129.5, $126.6(\mathrm{Cq}), 126.4(\mathrm{Cq}), 124.2(\mathrm{Cq}), 85.5,82.7,74.6$, $64.0\left(\mathrm{CH}_{2}\right), 48.0(\mathrm{Cq}), 39.7\left(\mathrm{CH}_{2}\right), 22.9\left(\mathrm{CH}_{2}\right), 21.9,21.8$, 21.7, 21.5, $15.4 \mathrm{ppm}$. For the critical NOESY correlations, see Figure S2 and copies of spectra (Supporting Information). 
1-(7-Ethyl-1-((2R,4S,5R)-4-hydroxy-5-(hydroxymethyl)tetrahydrofuran-2-yl)-1H-imidazo[4,5-c]pyridin-4-yl)-3,3,4,4tetramethylpyrrolidine-2,5-dione (18d). This compound was synthesized in a similar fashion to $\mathbf{1 8 i}$. To a solution of $\mathbf{1 7 d}$ $(0.46 \mathrm{~g}, 0.7 \mathrm{mmol})$ in dry $\mathrm{MeOH}(6 \mathrm{~mL})$ in a $25 \mathrm{~mL}$ roundbottom flask, NaOMe (114 mg, $2.11 \mathrm{mmol})$ was added. The mixture was stirred at room temperature under argon for $2 \mathrm{~h}$ and concentrated in vacuo. The product was purified by column chromatography on silica gel eluting with $0-10 \%$ $\mathrm{MeOH}$ in dichloromethane to obtain $\mathbf{1 8 d}$ as an off-white solid in $74 \%$ yield $\left(218 \mathrm{mg}\right.$ ). HRMS (ESI): $m / z[\mathrm{M}+\mathrm{H}]^{+}$calcd for $\mathrm{C}_{21} \mathrm{H}_{29} \mathrm{~N}_{4} \mathrm{O}_{5}$ : 417.21383; found: 417.21265. ${ }^{1} \mathrm{H}$ NMR (400 $\left.\mathrm{MHz}, \mathrm{CD}_{3} \mathrm{OD}\right): \delta, 8.74(\mathrm{~s}, 1 \mathrm{H}), 8.20(\mathrm{~s}, 1 \mathrm{H}), 6.63-6.60$ (dd, $J_{1}$ $\left.=6.4, J_{2}=12.8,1 \mathrm{H}\right), 4.58-4.55(\mathrm{~m}, 1 \mathrm{H}), 4.06-4.03($ app q, $J=$ 3.6, $1 \mathrm{H}$ ), 3.78-3.65 (m, 2H), 3.23-3.12 (app septet, $J=3.6$, $2 \mathrm{H}), 2.78-2.72(\mathrm{~m}, 1 \mathrm{H}), 2.60-2.54\left(\mathrm{ddd}, J_{1}=3.6, J_{2}=6.0, J_{3}=\right.$ $10.4,1 \mathrm{H}), 1.44-1.40(\mathrm{t}, J=7.6,3 \mathrm{H}), 1.37$ (bs, $12 \mathrm{H}) \mathrm{ppm} .{ }^{13} \mathrm{C}$ NMR (100 MHz, $\left.\mathrm{CD}_{3} \mathrm{OD}\right): \delta, 183.4(\mathrm{Cq}), 145.8(\mathrm{Cq}), 142.4$, $140.4(\mathrm{Cq}), 138.4(\mathrm{Cq}), 137.8(\mathrm{Cq}), 127.2(\mathrm{Cq}), 89.4,87.2$, 72.1, $62.7\left(\mathrm{CH}_{2}\right), 48.8(\mathrm{Cq}), 42.2\left(\mathrm{CH}_{2}\right), 23.5\left(\mathrm{CH}_{2}\right), 21.9$, 21.8, $15.7 \mathrm{ppm}$.

1-(1-((2R,4S,5R)-5-((Bis(4-methoxyphenyl)(phenyl)methoxy)methyl)-4-hydroxytetrahydrofuran-2-yl)-7-ethyl$1 \mathrm{H}$-imidazo[4,5-c]pyridin-4-yl)-3,3,4,4-tetramethylpyrrolidine-2,5-dione (19d). This compound was synthesized in a similar fashion to 19 i. To a solution of $18 \mathrm{~d}(190 \mathrm{mg}, 0.457$ mmol $)$ in pyridine $(3 \mathrm{~mL}), 4,4^{\prime}$-dimethoxytrityl chloride (DMT-Cl) (217 mg, $0.639 \mathrm{mmol}$ ) was added in one portion, and the mixture was stirred at room temperature under argon for $4 \mathrm{~h}$. The mixture was concentrated in vacuo. The product was purified by column chromatography on silica gel (neutralized with triethylamine) eluting with $0-20 \%$ acetone in dichloromethane to obtain $19 \mathbf{d}$ as a colorless solid in $33 \%$ yield $(110 \mathrm{mg})$. HRMS (ESI): $m / z[\mathrm{M}+\mathrm{H}]^{+}$calcd for $\mathrm{C}_{42} \mathrm{H}_{47} \mathrm{~N}_{4} \mathrm{O}_{7}$ : 719.34452; found: 719.34247. ${ }^{1} \mathrm{H}$ NMR (400 $\left.\mathrm{MHz}, \mathrm{CDCl}_{3}\right): \delta, 8.21(\mathrm{~s}, 1 \mathrm{H}), 8.16(\mathrm{~s}, 1 \mathrm{H}), 7.40-7.38$ (d, $J=$ $7.2,2 \mathrm{H}), 7.30-7.20(\mathrm{~m}, 7 \mathrm{H}), 6.82-6.80(\mathrm{~d}, J=9.2,4 \mathrm{H}), 6.42-$ $6.39\left(\mathrm{dd}, J_{1}=6.4, J_{2}=12.4,1 \mathrm{H}\right), 4.54-4.48(\mathrm{~m}, 1 \mathrm{H}), 4.11-$ $4.08(\operatorname{app~q}, J=4.4,1 \mathrm{H}), 3.77(\mathrm{~s}, 6 \mathrm{H}), 3.38-3.34$ (app dd, $J_{1}=$ $\left.4.4, J_{2}=10.4,1 \mathrm{H}\right), 3.32-3.29\left(\mathrm{app} d \mathrm{~d}, J_{1}=4.8, J_{2}=10.4,1 \mathrm{H}\right)$, 3.17 (bs, $1 \mathrm{H}$ ), 3.03-3.00 (app dd, $J_{1}=3.2, J_{2}=7.6,1 \mathrm{H}$ ), 2.99$2.96\left(\right.$ app dd, $\left.J_{1}=3.2, J_{2}=7.6,1 \mathrm{H}\right), 2.46-2.44($ app t $J=6.0$, $2 \mathrm{H}), 1.38-1.37$ (overlapped s, $12 \mathrm{H}), 1.36-1.32(\mathrm{t}, \mathrm{J}=7.2,3 \mathrm{H})$ ppm. ${ }^{13} \mathrm{C}$ NMR $\left(100 \mathrm{MHz}, \mathrm{CDCl}_{3}\right): \delta, 181.8(\mathrm{Cq}), 158.7$ (Cq), 144.5 (Cq), 142.6, 141.9, 138.9 (Cq), 137.3 (Cq), 137.2 (Cq), $135.63(\mathrm{Cq}), 135.58(\mathrm{Cq}), 130.1,128.13,128.06,127.1$, $124.6(\mathrm{Cq}), 113.4,86.8(\mathrm{Cq}), 86.0,85.2,71.9,63.7\left(\mathrm{CH}_{2}\right)$, 55.3, $48.0(\mathrm{Cq}), 41.7\left(\mathrm{CH}_{2}\right), 22.7\left(\mathrm{CH}_{2}\right), 21.8,21.4,15.3$ ppm.

(2R,3S,5R)-2-((Bis(4-methoxyphenyl)(phenyl)methoxy)methyl)-5-(7-ethyl-4-(3,3,4,4-tetramethyl-2,5-dioxopyrrolidin-1-yl)-1H-imidazo[4,5-c]pyridin-1-yl)tetrahydrofuran-3-yl (2-Cyanoethyl) Diisopropylphosphoramidite (20d). This compound was synthesized in a similar fashion to 20i. To a solution of $19 \mathrm{~d}(105 \mathrm{mg}, 0.146 \mathrm{mmol})$ in dry $\mathrm{CH}_{2} \mathrm{Cl}_{2}(4 \mathrm{~mL})$ containing $\mathrm{N}, \mathrm{N}$-diisopropylethylamine (DIEA) $(127 \mu \mathrm{L}, 0.731$ mmol), 2-cyanoethyl- $N, N$-diisopropyl chlorophosphoramidite (40 $\mu \mathrm{L}, 0.175 \mathrm{mmol}$ ) was added in one portion, and the mixture was stirred at room temperature under argon for $4 \mathrm{~h}$ (TLC showed complete conversion). The mixture was concentrated in vacuo at $\mathrm{rt}$, and the product was purified by column chromatography on silica gel (neutralized with triethylamine) eluting with $40-60 \%$ EtOAc in hexanes containing $1 \%$ triethylamine, to obtain $20 \mathrm{~d}$ as a mixture of diastereomers (white foam, $\mathrm{Rf} \sim 0.5$ in $5 \%$ acetone $/ \mathrm{CH}_{2} \mathrm{Cl}_{2}$, two close spots visible on TLC) in $67 \%$ yield $(90 \mathrm{mg})$. HRMS (ESI): $m / z[\mathrm{M}+\mathrm{H}]^{+}$calcd for $\mathrm{C}_{51} \mathrm{H}_{64} \mathrm{~N}_{6} \mathrm{O}_{8} \mathrm{P}$ : 919.45236; found: 919.45047. ${ }^{1} \mathrm{H} \mathrm{NMR}\left(400 \mathrm{MHz}, \mathrm{CDCl}_{3}\right): \delta, 8.25$ (s, $1 \mathrm{H}), 8.23,8.19(\mathrm{~s}, 1 \mathrm{H}), 7.40-7.38(\mathrm{~m}, 2 \mathrm{H}), 7.30-7.20(\mathrm{~m}$, $7 \mathrm{H}), 6.83-6.79(\mathrm{~m}, 4 \mathrm{H}), 6.49-6.46\left(\mathrm{dd}, J_{1}=6.8, J_{2}=13.6\right.$, $1 \mathrm{H}), 4.70-4.59(\mathrm{~m}, 1 \mathrm{H}), 4.32-4.24(\mathrm{~m}, 1 \mathrm{H}), 3.78,3.77(\mathrm{~s}$, $6 \mathrm{H}), 3.70-3.53(\mathrm{~m}, 3 \mathrm{H}), 3.32-3.31(\mathrm{~m}, 1 \mathrm{H}), 3.13-2.99(\mathrm{~m}$, $2 \mathrm{H}), 2.62-2.59(\mathrm{t}, J=6.4,1 \mathrm{H}), 2.57-2.55(\mathrm{~m}, 1 \mathrm{H}), 2.44-2.41$ $(\mathrm{t}, J=6.4,1 \mathrm{H}), 1.38,1.37$ (bs, $12 \mathrm{H}), 1.20-1.17(\mathrm{~m}, 9 \mathrm{H})$, $1.13-1.12(\mathrm{~d}, J=6.8,3 \mathrm{H}) \mathrm{ppm} .{ }^{13} \mathrm{C} \mathrm{NMR}\left(100 \mathrm{MHz}, \mathrm{CDCl}_{3}\right)$ : $\delta, 181.7,158.7,144.5,142.5,142.4,139.0,137.4,135.63$, $135.56,130.2,128.3,128.2,128.1,127.1,124.5,124.4,117.5$, $113.4,86.7,85.8,85.5,85.4,74.1,73.9,63.4,63.2,58.4,58.2$, 55.38, 55.36, 48.0, 43.61, 43.55, 43.4, 41.0, 24.7, 24.6, 22.9, 21.8, 21.5, 15.6 ppm. ${ }^{31} \mathrm{P}$ NMR (162 $\left.\mathrm{MHz}, \mathrm{CDCl}_{3}\right): \delta, 150.8$, $150.2 \mathrm{ppm}$.

7-Isobutyl-1H-imidazo[4,5-c]pyridin-4-amine, Trifluoroacetic Acid Salt (15e). This compound was synthesized in a similar fashion to $15 \mathrm{i}$. A solution of $14 \mathrm{e}(1.3 \mathrm{~g}, 2.4 \mathrm{mmol})$ in TFA $(20 \mathrm{~mL})$ was placed in a $100 \mathrm{~mL}$ pressure tube, anisole ( $1.6 \mathrm{~mL}, 6$ equiv) was added, and the mixture was heated at 70 ${ }^{\circ} \mathrm{C}$ for $24 \mathrm{~h}$ with vigorous stirring. It was cooled and concentrated under reduced pressure. The residue was coevaporated with toluene $(3 \times 20 \mathrm{~mL})$ to obtain $15 \mathrm{e}$ (ca. $0.8 \mathrm{~g}$, quantitative) as an oil that was taken into next step without further purification.

1-(7-Isobutyl-1H-imidazo[4,5-c]pyridin-4-yl)-3,3,4,4-tetramethylpyrrolidine-2,5-dione (16e). This compound was synthesized in a similar fashion to $16 \mathrm{i}$. A solution of $15 \mathrm{e}$ (ca. $0.8 \mathrm{~g}, 2.4 \mathrm{mmol})$ in pyridine $(20 \mathrm{~mL})$ was placed in a $100 \mathrm{~mL}$ Schlenk flask. Tetramethylsuccinic anhydride $\left(\mathrm{M}_{4} \mathrm{SA}\right)(0.8 \mathrm{~g}$, $5.1 \mathrm{mmol})$ and DBU $(1.5 \mathrm{~mL}, 10.0 \mathrm{mmol})$ were added, and the mixture was heated at $120{ }^{\circ} \mathrm{C}$ under argon for $22 \mathrm{~h}$ with vigorous stirring. It was cooled and concentrated under reduced pressure. The residue was coevaporated with toluene $(3 \times 20$ $\mathrm{mL}$ ). The product was purified by column chromatography on silica gel eluting with $0-5 \% \mathrm{MeOH}$ in $\mathrm{CH}_{2} \mathrm{Cl}_{2}$ to give a cream foam. It was taken in $\mathrm{SOCl}_{2}(20 \mathrm{~mL})$, heated at $80{ }^{\circ} \mathrm{C}$ for $2 \mathrm{~h}$, cooled, and concentrated under reduced pressure. The residue was coevaporated with EtOAc $(3 \times 20 \mathrm{~mL})$. The product was purified by column chromatography on silica gel eluting with $0-8 \% \mathrm{MeOH}$ in $\mathrm{CH}_{2} \mathrm{Cl}_{2}$ to give $16 \mathrm{e}$ as a cream foam in $79 \%$ yield (0.61 g). HRMS (ESI): $m / z[\mathrm{M}+\mathrm{H}]^{+}$calcd for $\mathrm{C}_{18} \mathrm{H}_{25} \mathrm{~N}_{4} \mathrm{O}_{2}$ : 329.19777; found: 329.19608. ${ }^{1} \mathrm{H}$ NMR (400 $\left.\mathrm{MHz}, \mathrm{CD}_{3} \mathrm{OD}\right): \delta, 8.43(\mathrm{~s}, 1 \mathrm{H}), 8.16(\mathrm{~s}, 1 \mathrm{H}), 2.87-2.85$ (d, $J=$ 7.6, 2H), 2.11-2.05 (app septet, $J=6.8,1 \mathrm{H}), 1.37$ (bs, $12 \mathrm{H}$ ), 0.99-0.97 (d, $J=6.4,6 \mathrm{H}) \mathrm{ppm} .{ }^{13} \mathrm{C} \mathrm{NMR}(100 \mathrm{MHz}$, $\left.\mathrm{CD}_{3} \mathrm{OD}\right): \delta, 183.2,146.4,143.7,141.6,135.8,135.4,126.0$, 38.9, 30.4, 22.6, $21.9 \mathrm{ppm}$.

(2R,3S,5R)-5-(7-Isobutyl-4-(3,3,4,4-tetramethyl-2,5-dioxopyrrolidin-1-yl)-1H-imidazo[4,5-c]pyridin-1-yl)-2-((4methylbenzoyl)oxy)methyl)tetrahydrofuran-3-yl 4-Methylbenzoate (17e). This compound was synthesized in a similar fashion to $17 \mathrm{i}$. To a solution of $16 \mathrm{e}(0.585 \mathrm{~g}, 1.78 \mathrm{mmol})$ in dry $\mathrm{CH}_{3} \mathrm{CN}(60 \mathrm{~mL})$ in a $250 \mathrm{~mL}$ round-bottom flask, $60 \% \mathrm{NaH}$ in oil (143 mg, $3.57 \mathrm{mmol}$ ) was added, and the mixture was vigorously stirred at room temperature under argon for $35 \mathrm{~min}$. 1-( $\alpha$ )-Chloro-3,5-di- $O$-( $p$-toluoyl)-2-deoxy-D-ribose (1.25 g, $3.21 \mathrm{mmol}$ ) was subsequently added portionwise over $1 \mathrm{~h}$, and the stirring was continued at room temperature for overall $4.5 \mathrm{~h}$. The mixture was filtered through Celite and concentrated. The product was purified by column chromatog- 
raphy on silica gel eluting with $0-50 \%$ EtOAc in hexanes and concentrated repeatedly with dichloromethane. Compound $17 \mathrm{e}$ was obtained as a yellowish solid in $38 \%$ yield $(0.465 \mathrm{~g})$. HRMS (ESI): $m / z[\mathrm{M}+\mathrm{H}]^{+}$calcd for $\mathrm{C}_{39} \mathrm{H}_{45} \mathrm{~N}_{4} \mathrm{O}_{7}: 681.32887$; found: 681.32697. ${ }^{1} \mathrm{H}$ NMR $\left(400 \mathrm{MHz}, \mathrm{CDCl}_{3}\right): \delta, 8.27(\mathrm{~s}, 1 \mathrm{H}), 8.20$ $(\mathrm{s}, 1 \mathrm{H}), 7.97-7.95(\mathrm{~d}, J=8.0,2 \mathrm{H}), 7.92-7.90(\mathrm{~d}, J=8.0,2 \mathrm{H})$, $7.30-7.28(\mathrm{~d}, J=8.4,2 \mathrm{H}), 7.27-7.25(\mathrm{~d}, J=8.4,2 \mathrm{H}), 6.59-$ $6.55\left(\mathrm{dd}, J_{1}=5.2, J_{2}=8.8,1 \mathrm{H}\right), 5.73-5.72(\mathrm{~m}, 1 \mathrm{H}), 4.70-4.61$ $(\mathrm{m}, 3 \mathrm{H}), 2.98-2.92\left(\mathrm{dd}, J_{1}=7.2, J_{2}=14.4,1 \mathrm{H}\right), 2.84-2.72(\mathrm{~m}$, $3 \mathrm{H}), 2.45$ (s, 3H), 2.42 (s, 3H), 1.98-1.88 (app septet, $J=6.4$, $1 \mathrm{H}), 1.38$ (bs, $1 \mathrm{H}), 1.05-1.03(\mathrm{~d}, J=6.8,6 \mathrm{H}) \mathrm{ppm} .{ }^{13} \mathrm{C} \mathrm{NMR}$ $\left(100 \mathrm{MHz} \mathrm{CDCl}_{3}\right): \delta, 181.6(\mathrm{Cq}), 166.3(\mathrm{Cq}), 165.9(\mathrm{Cq})$, $144.9(\mathrm{Cq}), 144.4(\mathrm{Cq}), 144.1,142.2,139.2(\mathrm{Cq}), 137.7(\mathrm{Cq})$, 137.4 (Cq), 129.9, 129.8, 129.54, 129.47, 126.6 (Cq), 126.3 (Cq), $121.8(\mathrm{Cq}), 85.4,82.9,74.9,64.2\left(\mathrm{CH}_{2}\right), 48.0(\mathrm{Cq}), 39.9$ $\left(\mathrm{CH}_{2}\right), 39.1\left(\mathrm{CH}_{2}\right), 30.2,22.5,21.9,21.8,21.7,21.5$ ppm. For the critical NOESY correlations, see Figure S3 and copies of spectra (Supporting Information).

1 - (1-((2R,4S,5R)-4-Hydroxy-5-(hydroxymethyl)tetrahydrofuran-2-yl)-7-isobutyl-1H-imidazo[4,5-c]pyridin-4yl)-3,3,4,4-tetramethylpyrrolidine-2,5-dione (18e). This compound was synthesized in a similar fashion to $18 \mathrm{i}$. To a solution of $17 \mathrm{e}(0.46 \mathrm{~g}, 0.68 \mathrm{mmol})$ in dry $\mathrm{MeOH}(7 \mathrm{~mL})$ in a $25 \mathrm{~mL}$ round-bottom flask, $\mathrm{NaOMe}(110 \mathrm{mg}, 2.03 \mathrm{mmol})$ was added. The mixture was stirred at room temperature under argon for 2 $\mathrm{h}$ and concentrated in vacuo. The product was purified by column chromatography on silica gel eluting with $0-10 \%$ $\mathrm{MeOH}$ in dichloromethane to obtain 18e as an off-white foam in $85 \%$ yield $\left(256 \mathrm{mg}\right.$ ). HRMS (ESI): $m / z[\mathrm{M}+\mathrm{H}]^{+}$calcd for $\mathrm{C}_{23} \mathrm{H}_{33} \mathrm{~N}_{4} \mathrm{O}_{5}$ : 445.24512; found: 445.24381. ${ }^{1} \mathrm{H}$ NMR (400 $\left.\mathrm{MHz}, \mathrm{CD}_{3} \mathrm{OD}\right): \delta, 8.74(\mathrm{~s}, 1 \mathrm{H}), 8.14(\mathrm{~s}, 1 \mathrm{H}), 6.58-6.55$ (dd, $J_{1}$ $\left.=6.4, J_{2}=12.8,1 \mathrm{H}\right), 4.58-4.55\left(\mathrm{dt}, J_{1}=3.2, J_{2}=6.8,1 \mathrm{H}\right)$, 4.06-4.04 (app q, $J=3.2,1 \mathrm{H}), 3.77-3.73\left(\right.$ app dd, $J_{1}=3.6, J_{2}$ $=12.0,1 \mathrm{H}), 3.72-3.68\left(\mathrm{app} d \mathrm{~d}, J_{1}=3.6, J_{2}=12.0,1 \mathrm{H}\right), 3.06-$ $3.01\left(\right.$ app dd, $\left.J_{1}=6.8, J_{2}=14.4,1 \mathrm{H}\right), 2.92-2.86\left(\right.$ app dd, $J_{1}=$ $\left.7.2, J_{2}=14.0,1 \mathrm{H}\right), 2.76-2.69\left(\mathrm{ddd}, J_{1}=5.6, J_{2}=6.8, J_{3}=13.2\right.$, $1 \mathrm{H}), 2.56-2.51\left(\mathrm{ddd}, J_{1}=3.6, J_{2}=6.0, J_{3}=9.6,1 \mathrm{H}\right), 2.04-1.94$ (app septet, $J=6.8,1 \mathrm{H}), 1.37$ (bs, $12 \mathrm{H}), 1.05-1.03(\mathrm{~d}, J=6.8$, $6 \mathrm{H}) \mathrm{ppm} .{ }^{13} \mathrm{C} \mathrm{NMR}\left(100 \mathrm{MHz}, \mathrm{CD}_{3} \mathrm{OD}\right): \delta, 183.4(\mathrm{Cq})$, $146.0(\mathrm{Cq}), 144.0,140.7(\mathrm{Cq}), 138.5(\mathrm{Cq}), 137.9(\mathrm{Cq}), 124.6$ (Cq), 89.4, 87.0, 72.3, $62.8\left(\mathrm{CH}_{2}\right), 48.9(\mathrm{Cq}), 42.3\left(\mathrm{CH}_{2}\right), 39.4$ $\left(\mathrm{CH}_{2}\right), 31.1,22.6,22.5,21.9,21.8 \mathrm{ppm}$.

1-(1-((2R,4S,5R)-5-((Bis(4-methoxyphenyl)(phenyl)methoxy)methyl)-4-hydroxytetrahydrofuran-2-yl)-7-isobutyl-1H-imidazo[4,5-c]pyridin-4-yl)-3,3,4,4-tetramethylpyrrolidine-2,5-dione (19e). This compound was synthesized in a similar fashion to 19 i. To a solution of $18 \mathrm{e}(225 \mathrm{mg}, 0.507$ $\mathrm{mmol})$ in dry pyridine $(4 \mathrm{~mL}), 4,4^{\prime}$-dimethoxytrityl chloride (DMT-Cl) $(240 \mathrm{mg}, 0.709 \mathrm{mmol})$ was added in one portion, and the mixture was stirred at room temperature under argon for $4 \mathrm{~h}$. TLC analysis indicated that a lot of starting material remained and then additional DMT-Cl $(0.120 \mathrm{~g}, 0.355 \mathrm{mmol})$ and cat. 4-dimethylaminopyridine (DMAP) (10 mg) were added. After $14 \mathrm{~h}$, more DMT-Cl $(0.120 \mathrm{~g}, 0.350 \mathrm{mmol})$, triethylamine $(85 \mu \mathrm{L}, 0.608 \mathrm{mmol})$, and cat. DMAP $(10 \mathrm{mg})$ were added. After $8 \mathrm{~h}$, another portion as above was added, and after $16 \mathrm{~h}$, TLC showed no further conversion (overall $42 \mathrm{~h}$ ). The mixture was quenched with $200 \mu \mathrm{L}$ of $\mathrm{MeOH}$, concentrated in vacuo, the residue was taken in AcOEt and filtered, and the filtrate was concentrated in vacuo. The product was purified by column chromatography on silica gel (neutralized with triethylamine) eluting with $0-25 \%$ acetone in dichloromethane to obtain 19e as a colorless foam in $46 \%$ yield (175 mg). Further elution with $10 \% \mathrm{MeOH}$ in dichloromethane yielded the recovered starting material $18 \mathbf{e}$ as a colorless syrup in $45 \%$ yield (102 mg). HRMS (ESI): $\mathrm{m} / z$ $[\mathrm{M}+\mathrm{H}]^{+}$calcd for $\mathrm{C}_{44} \mathrm{H}_{51} \mathrm{~N}_{4} \mathrm{O}_{7}$ : 747.37582; found: 747.37412. ${ }^{1} \mathrm{H}$ NMR (400 MHz, $\left.\mathrm{CDCl}_{3}\right): \delta, 8.17(\mathrm{~s}, 1 \mathrm{H}), 8.14(\mathrm{~s}, 1 \mathrm{H})$, $7.40-7.38(\mathrm{~d}, J=8.8,2 \mathrm{H}), 7.30-7.20(\mathrm{~m}, 7 \mathrm{H}), 6.82-6.80(\mathrm{~d}, J$ $=8.8,4 \mathrm{H}), 6.42-6.38\left(\mathrm{dd}, J_{1}=6.4, J_{2}=12.8,1 \mathrm{H}\right), 4.52-4.51$ (m, 1H), 4.10-4.07 (app q, $J=4.4,1 \mathrm{H}), 3.77$ (s, 6H), 3.38$3.35\left(\right.$ app dd, $\left.J_{1}=4.4, J_{2}=10.4,1 \mathrm{H}\right), 3.33-3.29\left(\right.$ app dd, $J_{1}=$ $\left.4.8, J_{2}=10.4,1 \mathrm{H}\right), 2.88-2.83\left(\right.$ app dd, $\left.J_{1}=7.2, J_{2}=14.4,1 \mathrm{H}\right)$, $2.75-2.70\left(\right.$ app dd, $\left.J_{1}=6.4, J_{2}=14.0,1 \mathrm{H}\right), 2.46-2.41(\mathrm{~m}, 2 \mathrm{H})$, 1.90-1.84 (app quintet, $J=6.4,1 \mathrm{H}$ ), 1.37-1.36 (overlapped $\mathrm{s}$, $12 \mathrm{H}), 1.01-0.99\left(\mathrm{dd}, J_{1}=2.4, J_{2}=6.4,6 \mathrm{H}\right) \mathrm{ppm} .{ }^{13} \mathrm{C} \mathrm{NMR}$ $\left(100 \mathrm{MHz}, \mathrm{CDCl}_{3}\right): \delta, 181.7(\mathrm{Cq}), 158.7(\mathrm{Cq}), 144.5(\mathrm{Cq})$, 143.6, 142.7, $139.2(\mathrm{Cq}), 137.5(\mathrm{Cq}), 137.4(\mathrm{Cq}), 135.63(\mathrm{Cq})$, $135.58(\mathrm{Cq}), 130.1,128.2,128.1,127.1,122.2(\mathrm{Cq}), 113.4,86.8$ (Cq), 86.0, 85.0, 72.0, $63.7\left(\mathrm{CH}_{2}\right), 55.3,48.0(\mathrm{Cq}), 41.8$ $\left(\mathrm{CH}_{2}\right), 38.8\left(\mathrm{CH}_{2}\right), 30.1,22.5,22.4,21.8,21.4 \mathrm{ppm}$.

(2R,3S,5R)-2-((Bis(4-methoxyphenyl)(phenyl)methoxy)methyl)-5-(7-isobutyl-4-(3,3,4,4-tetramethyl-2,5-dioxopyrrolidin-1-yl)-1H-imidazo[4,5-c]pyridin-1-yl)tetrahydrofuran-3yl (2-Cyanoethyl) Diisopropylphosphoramidite (20e). This compound was synthesized in a similar fashion to 20i. To a solution of $19 \mathrm{e}(105 \mathrm{mg}, 0.146 \mathrm{mmol})$ in dry $\mathrm{CH}_{2} \mathrm{Cl}_{2}(5 \mathrm{~mL})$ containing $N, N$-diisopropylethylamine (DIEA) $(185 \mu \mathrm{L}, 1.07$ $\mathrm{mmol}$ ), 2-cyanoethyl- $N, N$-diisopropyl chlorophosphoramidite (105 $\mu \mathrm{L}, 0.472 \mathrm{mmol}$ ) was added in one portion, and the mixture was stirred at room temperature under argon for $4 \mathrm{~h}$ (TLC showed complete conversion). The mixture was concentrated in vacuo at $\mathrm{rt}$, and the product was purified by column chromatography on silica gel (neutralized with triethylamine) eluting with $40-60 \%$ EtOAc in hexanes containing $1 \%$ triethylamine, to obtain $20 \mathrm{e}$ as a mixture of diastereomers (white foam, $R_{\mathrm{f}} \sim 0.5$ in $50 \%$ EtOAc in hexanes, two close spots visible on TLC) in 59\% yield $(120 \mathrm{mg})$. HRMS (ESI): $m / z[\mathrm{M}+\mathrm{H}]^{+}$calcd for $\mathrm{C}_{53} \mathrm{H}_{68} \mathrm{~N}_{6} \mathrm{O}_{8} \mathrm{P}$ : 947.48366; found: 947.48314. ${ }^{1} \mathrm{H}$ NMR (400 MHz, acetone- $\left.d_{6}\right): \delta$, 8.43, $8.41(\mathrm{~s}, 1 \mathrm{H}), 8.15(\mathrm{~s}, 1 \mathrm{H}), 7.46-7.41(\mathrm{~m}, 2 \mathrm{H}), 7.33-7.19(\mathrm{~m}$, $7 \mathrm{H}), 6.85-6.81(\mathrm{~m}, 4 \mathrm{H}), 6.62-6.58\left(\mathrm{dd}, J_{1}=6.4, J_{2}=13.2\right.$, $1 \mathrm{H}), 4.86-4.81(\mathrm{~m}, 1 \mathrm{H}), 4.37-4.29(\mathrm{~m}, 1 \mathrm{H}), 3.96-3.82(\mathrm{~m}$, $1 \mathrm{H}), 3.77,3.76(\mathrm{~s}, 6 \mathrm{H}), 3.74-3.66(\mathrm{~m}, 2 \mathrm{H}), 3.39-3.34(\mathrm{~m}$, $2 \mathrm{H}), 3.13-3.09(\mathrm{~m}, 1 \mathrm{H}), 3.03-2.96(\mathrm{~m}, 1 \mathrm{H}), 2.94-2.87(\mathrm{~m}$, $1 \mathrm{H}), 2.81(\mathrm{~m}, 3 \mathrm{H}), 2.79-2.76(\mathrm{t}, J=6.4,1 \mathrm{H}), 2.68-2.64(\mathrm{t}, J=$ $6.0,1 \mathrm{H}), 1.36,1.35,1.30$ (bs, $12 \mathrm{H}), 1.23-1.21,1.22-1.20$, $1.17-1.16(\mathrm{~d}, J=6.8,12 \mathrm{H}), 1.08-1.06(\mathrm{~d}, J=6.8,3 \mathrm{H}), 1.05-$ $1.03\left(\mathrm{dd}, J_{1}=1.6, J_{2}=6.4,3 \mathrm{H}\right) \mathrm{ppm} .{ }^{13} \mathrm{C}$ NMR $(100 \mathrm{MHz}$, acetone- $\left.d_{6}\right): \delta, 181.8,159.6,145.9,144.1,144.0,139.9,138.7$, $136.6,136.5,131.0,130.9,129.0,128.9,128.6,127.6,123.32$, $123.28,119.0,114.0,87.2,86.7,86.1,86.0,75.0,74.9,74.5$, $74.3,64.5,59.6,59.4,55.5,48.4,44.1,44.0,40.4,39.0,25.0$, 24.9, 24.8, 22.9, 22.5, 22.0, 21.7, 21.4, 20.8 ppm. ${ }^{31} \mathrm{P}$ NMR (162 $\mathrm{MHz}$, acetone- $\left.d_{6}\right): \delta, 149.9,149.7 \mathrm{ppm}$.

7-Phenyl-1H-imidazo[4,5-c]pyridin-4-amine, Trifluoroacetic Acid Salt (15a, 3a*TFA). This compound was synthesized in a similar fashion to $15 \mathrm{i}$. A solution of $\mathbf{1 4 a}(2.09 \mathrm{~g}, 3.65$ $\mathrm{mmol})$ in TFA $(20 \mathrm{~mL})$ was placed in a $100 \mathrm{~mL}$ pressure tube, anisole $(2.4 \mathrm{~mL}, 6$ equiv) was added, and the mixture was heated at $70{ }^{\circ} \mathrm{C}$ for $24 \mathrm{~h}$ with vigorous stirring. It was cooled and concentrated under reduced pressure. The residue was coevaporated with toluene $(3 \times 25 \mathrm{~mL})$ to obtain a gray-brown powder. It was taken in toluene $(10 \mathrm{~mL})$ and filtered, washed with toluene $(2 \times 5 \mathrm{~mL})$ and hexanes $(2 \times 5 \mathrm{~mL})$, and dried in air to obtain 15a as a free-flowing, light gray powder, $1.13 \mathrm{~g}$ 
(quantitative). MS (ESI): $m / z, 211.3$ for $[\mathrm{M}+\mathrm{H}]^{+} .{ }^{1} \mathrm{H}$ NMR $\left(400 \mathrm{MHz}, \mathrm{DMSO}-d_{6}\right): \delta, 8.60(\mathrm{bs}, 2 \mathrm{H}), 8.52(\mathrm{~s}, 1 \mathrm{H}), 7.82(\mathrm{~s}$, $1 \mathrm{H}), 7.70-7.69(\mathrm{~m}, 2 \mathrm{H}), 7.56-7.53(\mathrm{~m}, 2 \mathrm{H}), 7.49-7.46(\mathrm{~m}$, $1 \mathrm{H}) \mathrm{ppm} .{ }^{13} \mathrm{C}$ NMR $\left(100 \mathrm{MHz}, \mathrm{DMSO}-d_{6}\right): \delta, 159.4,159.0$, $158.7,158.3,147.5,144.3,132.7,129.1,128.5,128.0,126.7$, $115.2 \mathrm{ppm}$.

3,3,4,4-Tetramethyl-1-(7-phenyl-1H-imidazo[4,5-c]pyridin-4-yl)pyrrolidine-2,5-dione (16a). This compound was synthesized in a similar fashion to 16i. A solution of $\mathbf{1 5 a}(0.34$ $\mathrm{g}, 1 \mathrm{mmol})$ in pyridine $(10 \mathrm{~mL})$ was placed in a $100 \mathrm{~mL}$ Schlenk flask. Tetramethylsuccinic anhydride $\left(\mathrm{M}_{4} \mathrm{SA}\right)(0.546 \mathrm{~g}$, $3.5 \mathrm{mmol})$ and DBU $(1.05 \mathrm{~mL}, 7 \mathrm{mmol})$ were added, and the mixture was heated at $120{ }^{\circ} \mathrm{C}$ under argon for $20 \mathrm{~h}$ with vigorous stirring. It was cooled and concentrated under reduced pressure. The residue was coevaporated with toluene $(3 \times 25$ $\mathrm{mL}$ ). The product was purified by column chromatography on silica gel eluting with $0-5 \% \mathrm{MeOH}$ in $\mathrm{CH}_{2} \mathrm{Cl}_{2}$ to give a colorless syrup. It was taken in $\mathrm{SOCl}_{2}(12 \mathrm{~mL})$, heated at $80{ }^{\circ} \mathrm{C}$ for $2 \mathrm{~h}$, cooled, and concentrated under reduced pressure. The residue was coevaporated with EtOAc $(3 \times 25 \mathrm{~mL})$. The product was purified by column chromatography on silica gel eluting with $0-5 \% \mathrm{MeOH}$ in $\mathrm{CH}_{2} \mathrm{Cl}_{2}$ to give 16a as a light brown foam in $92 \%$ yield (0.56 g). HRMS (ESI): $m / z[\mathrm{M}+$ $\mathrm{H}]^{+}$calcd for $\mathrm{C}_{20} \mathrm{H}_{21} \mathrm{~N}_{4} \mathrm{O}_{2}$ : 349.16647; found: $349.16505 .{ }^{1} \mathrm{H}$ NMR (400 MHz, CD 3 OD): $\delta, 8.75(\mathrm{~s}, 1 \mathrm{H}), 8.52(\mathrm{~s}, 1 \mathrm{H})$, 7.76-7.75 (m, 2H), 7.61-7.51 (m, 3H), 1.40 (bs, 12H) ppm. ${ }^{13} \mathrm{C}$ NMR (100 MHz, $\left.\mathrm{CD}_{3} \mathrm{OD}\right): \delta, 182.5,147.9,142.4,139.6$, 135.4, 134.4, 134.3, 130.5, 129.8, 127.0, 49.1, $21.8 \mathrm{ppm}$.

((2R,3S,5R)-3-((4-Methylbenzoyl)oxy)-5-(7-phenyl-4(3,3,4,4-tetramethyl-2,5-dioxopyrrolid-in-1-yl)-1H-imidazo[4,5-c]pyridin-1-yl)tetrahydrofuran-2-yl)methyl 4-Methylbenzoate (17a). This compound was synthesized in a similar fashion to $17 \mathbf{i}$. To a solution of $16 \mathrm{a}(0.51 \mathrm{~g}, 1.46 \mathrm{mmol})$ in dry $\mathrm{CH}_{3} \mathrm{CN}(60 \mathrm{~mL})$ in a $100 \mathrm{~mL}$ round-bottom flask, $60 \% \mathrm{NaH}$ in oil (117 mg, $2.93 \mathrm{mmol})$ was added, and the mixture was vigorously stirred at room temperature under argon for $45 \mathrm{~min}$. 1- $(\alpha)$-Chloro-3,5-di-O-( $p$-toluoyl)-2-deoxy-D-ribose (0.368 g, $0.94 \mathrm{mmol}$ ) was subsequently added portionwise over $1 \mathrm{~h}$, and the stirring was continued at room temperature for overall $5 \mathrm{~h}$. The mixture was filtered through Celite and concentrated. The product was purified by column chromatography on silica gel eluting with $0-50 \%$ EtOAc in hexanes. Compound 17a was obtained as a yellowish syrup in $64 \%$ yield $(0.64 \mathrm{~g})$. HRMS (ESI): $m / z[\mathrm{M}+\mathrm{H}]^{+}$calcd for $\mathrm{C}_{41} \mathrm{H}_{40} \mathrm{~N}_{4} \mathrm{O}_{7}$ : 701.29757; found: 701.29626. ${ }^{1} \mathrm{H}$ NMR $\left(400 \mathrm{MHz}, \mathrm{CDCl}_{3}\right): \delta, 8.33$ (s, 1H), 8.31 (s, $1 \mathrm{H}), 7.86-7.84(\mathrm{~d}, J=8.0,2 \mathrm{H}), 7.75-7.73(\mathrm{~d}, J=8.0,2 \mathrm{H})$, 7.46 (bs, $4 \mathrm{H}), 7.32-7.28(\mathrm{~m}, 1 \mathrm{H}), 7.31-7.29(\mathrm{~d}, J=8.0,2 \mathrm{H})$, $7.24-7.22(\mathrm{~d}, J=8.0,2 \mathrm{H}), 5.96-5.93\left(\mathrm{dd}, J_{1}=5.2, J_{2}=8.8\right.$, $1 \mathrm{H}), 5.46-5.44(\mathrm{~m}, 1 \mathrm{H}), 4.62-4.53(\mathrm{~m}, 2 \mathrm{H}), 4.38-4.36(\mathrm{~m}$, $1 \mathrm{H}), 2.48(\mathrm{~s}, 3 \mathrm{H}), 2.40(\mathrm{~s}, 3 \mathrm{H}), 2.30-2.16(\mathrm{~m}, 2 \mathrm{H}), 1.40$ (bs, $12 \mathrm{H})$ ppm. ${ }^{13} \mathrm{C}$ NMR $\left(100 \mathrm{MHz}, \mathrm{CDCl}_{3}\right): \delta, 181.7(\mathrm{Cq}), 166.2$ $(\mathrm{Cq}), 165.6(\mathrm{Cq}), 144.7(\mathrm{Cq}), 144.5(\mathrm{Cq}), 142.9,142.7,138.4$ (Cq), 138.0 (Cq), 137.4 (Cq), 134.8 (Cq), 130.0, 129.7, 129.6, 129.3, 129.0, 128.8, $126.6(\mathrm{Cq}), 126.4(\mathrm{Cq}), 123.5(\mathrm{Cq}), 85.9$, 82.8, 74.9, $64.2\left(\mathrm{CH}_{2}\right), 48.1(\mathrm{Cq}), 40.1\left(\mathrm{CH}_{2}\right), 21.9,21.8,21.6$ ppm. For the critical NOESY correlations, see Figure S4 and copies of spectra (Supporting Information).

1 - (1-((2R,4S, 5R)-4-Hydroxy-5-(hydroxymethyl)tetrahydrofuran-2-yl)-7-phenyl-1H-imidazo[4,5-c]pyridin-4yl)-3,3,4,4-tetramethylpyrrolidine-2,5-dione (18a). This compound was synthesized in a similar fashion to $18 \mathrm{i}$. To a solution of $17 \mathrm{a}(0.44 \mathrm{~g}, 0.63 \mathrm{mmol})$ in dry $\mathrm{MeOH}(6 \mathrm{~mL})$ in a $25 \mathrm{~mL}$ round-bottom flask, $\mathrm{NaOMe}(102 \mathrm{mg}, 1.89 \mathrm{mmol})$ was added, and the mixture was stirred at room temperature under argon for $2 \mathrm{~h}$. It was concentrated in vacuo, and the product was purified by column chromatography on silica gel eluting with $0-10 \% \mathrm{MeOH}$ in $\mathrm{CH}_{2} \mathrm{Cl}_{2}$ to obtain 18a as a white foam in $58 \%$ yield $(0.17 \mathrm{~g})$. HRMS (ESI): $m / z[\mathrm{M}+\mathrm{H}]^{+}$calcd for $\mathrm{C}_{25} \mathrm{H}_{29} \mathrm{~N}_{4} \mathrm{O}_{5}$ : 465.21383; found: 465.21228. ${ }^{1} \mathrm{H}$ NMR (400 $\left.\mathrm{MHz}, \mathrm{CD}_{3} \mathrm{OD}\right): \delta, 8.85(\mathrm{~s}, 1 \mathrm{H}), 8.19(\mathrm{~s}, 1 \mathrm{H}), 7.56(\mathrm{~m}, 5 \mathrm{H})$, 5.97-5.94 (t, $J=6.0,1 \mathrm{H}), 4.37-4.33(\mathrm{~m}, 1 \mathrm{H}), 3.78-3.65(\mathrm{~m}$, $3 \mathrm{H}), 2.35-2.28(\mathrm{~m}, 1 \mathrm{H}), 1.96-1.90\left(\mathrm{ddd}, J_{1}=4.4, J_{2}=6.0, J_{3}=\right.$ 10.8, 1H), 1.39 (bs, $12 \mathrm{H})$ ppm. ${ }^{13} \mathrm{C}$ NMR (100 MHz, $\left.\mathrm{CD}_{3} \mathrm{OD}\right): \delta, 183.4(\mathrm{Cq}), 146.5(\mathrm{Cq}), 143.1,139.4(\mathrm{Cq}), 138.7$ $(\mathrm{Cq}), 138.6(\mathrm{Cq}), 135.6(\mathrm{Cq}), 130.9,130.2,129.9,126.0(\mathrm{Cq})$, 88.9, 87.1, 71.2, $62.3\left(\mathrm{CH}_{2}\right), 49.0(\mathrm{Cq}), 42.9\left(\mathrm{CH}_{2}\right), 21.9,21.8$ ppm.

The attempted tritylation of $\mathbf{1 8 a}$ was carried forward in a similar fashion to $\mathbf{1 8 i}$. To a solution of 18 a ( $0.15 \mathrm{~g}, 0.323$ $\mathrm{mmol})$ in pyridine $(3 \mathrm{~mL})$ under $\mathrm{Ar}, 4,4^{\prime}$-dimethoxytrityl chloride (DMT-Cl) $(0.153 \mathrm{~g}, 0.453 \mathrm{mmol})$ was added in one portion, and the mixture was stirred at room temperature for 4.5 h. TLC analysis indicated that some starting material remained and then additional DMT-Cl was added (0.076 g, $0.225 \mathrm{mmol})$. After $3.5 \mathrm{~h}$, the starting material still remained and then triethylamine $(45 \mu \mathrm{L}, 0.323 \mathrm{mmol})$, cat. DMAP (10 $\mathrm{mg}$ ), and additional DMT-Cl (44 mg, $0.129 \mathrm{mmol}$ ) were added. After $8 \mathrm{~h}$, most of the starting material was consumed, the mixture was concentrated in vacuo, and the residue was coevaporated with toluene $(3 \times 10 \mathrm{~mL})$ to remove residual pyridine. A TLC analysis indicated that an extensive deglycosylation occurred, indicating the instability of the compound, which may be ascribed to the electronic character of phenyl group at the position 3, as suggested by other reports. ${ }^{15}$ Deglycosylation was also observed to occur upon mild heating of the TLC plate to remove pyridine before analysis.

Synthesis of 3-Deazahypoxanthine 21c. 7-Phenethyl1H-imidazo[4,5-c]pyridin-4-amine, Trifluoroacetic Acid Salt (15c). This compound was synthesized in a similar fashion to 15i. A solution of $14 \mathrm{c}(0.327 \mathrm{~g}, 0.55 \mathrm{mmol})$ in TFA $(8 \mathrm{~mL})$ was placed in a $100 \mathrm{~mL}$ pressure tube, anisole $(0.36 \mathrm{~mL}, 6$ equiv) was added, and the mixture was heated at $70{ }^{\circ} \mathrm{C}$ for $21 \mathrm{~h}$ with vigorous stirring. It was cooled and concentrated under reduced pressure. The residue was coevaporated with toluene $(3 \times 15 \mathrm{~mL})$ to obtain $15 \mathrm{c}$ (ca. $0.2 \mathrm{~g}$, quantitative) as a syrup that was taken into next step without further purification.

7-Phenethyl-1,5-dihydro-4H-imidazo[4,5-c]pyridin-4-one (21c). This compound was synthesized according to the general procedure. ${ }^{56}$ To a solution of crude $15 \mathrm{c}(\mathrm{ca} .0 .2 \mathrm{~g}, 0.55 \mathrm{mmol})$ in acetone $/ \mathrm{H}_{2} \mathrm{O} / \mathrm{AcOH}(4 / 2 / 2 \mathrm{~mL})$ was added $\mathrm{NaNO}_{2}$ in one portion $(0.755 \mathrm{~g}, 10.9 \mathrm{mmol})$ and stirred at room temperature for $5 \mathrm{~h}$ in a closed vessel. The pressure was carefully released, and the mixture was carefully neutralized with aq $\mathrm{NaHCO}_{3}$ and diluted with $\mathrm{Et}_{2} \mathrm{O}(50 \mathrm{~mL})$. The phases were shaken, and the precipitated solid was filtered, washed with water and $\mathrm{Et}_{2} \mathrm{O}$, and dried in air to obtain $21 \mathrm{c}$ as a light yellow solid $(75 \mathrm{mg}, 57 \%$ based on 14c). HRMS (ESI): $m / z[\mathrm{M}+\mathrm{H}]^{+}$calcd for $\mathrm{C}_{14} \mathrm{H}_{14} \mathrm{~N}_{3} \mathrm{O}: 240.11369$; found: 240.11281. MS (ESI): $m / z$, 240.3 for $[\mathrm{M}+\mathrm{H}]^{+}, 262.2$ for $[\mathrm{M}+\mathrm{Na}]^{+}, 501.2$ for $[2 \mathrm{M}+$ $\mathrm{Na}]^{+} ; 238.3$ for $[\mathrm{M}-\mathrm{H}]^{-} .{ }^{1} \mathrm{H}$ NMR $\left(400 \mathrm{MHz}\right.$, DMSO- $\left.d_{6}\right): \delta$, 10.9 (bs, $1 \mathrm{H}), 8.09$ (s, $1 \mathrm{H}), 7.26-7.16(\mathrm{~m}, 5 \mathrm{H}), 6.79(\mathrm{~s}, 1 \mathrm{H})$, 2.93-2.89 (m, 4H) ppm. ${ }^{13} \mathrm{C}$ NMR (100 MHz, DMSO- $\left.d_{6}\right): \delta$, 156.1, 141.6, 141.2, 128.4, 128.2, 125.8, 124.9, 110.7, 35.1, 29.7 ppm. 
Purification of Salts 15. TFA salts 15 were used for synthetic purposes typically without further purification. Pure amines could be also isolated as water-soluble $\mathrm{HCl}$ salts as exemplified below. Free amines could be obtained by neutralization of their aqueous solutions with $\mathrm{Na}_{2} \mathrm{CO}_{3}$, followed by extraction with AcOEt.

7-Phenethyl-1H-imidazo[4,5-c]pyridin-4-amine, Hydrochloric Acid Salt (15c*HCl). A solution of $14 \mathrm{c}(0.173 \mathrm{~g}, 0.29$ $\mathrm{mmol})$ in $\mathrm{EtOH} / \mathrm{H}_{2} \mathrm{O} / \mathrm{HCl}$ conc. $(8 / 8 / 4 \mathrm{~mL})$ was heated under reflux condenser at $100{ }^{\circ} \mathrm{C}$ for $23 \mathrm{~h}$. It was cooled, and $\mathrm{EtOH}$ was removed under reduced pressure. It was diluted with aq $\mathrm{HCl}$ and washed with $\mathrm{Et}_{2} \mathrm{O}(40 \mathrm{~mL}$, discarded $)$ to remove a precipitated oil. The residue was concentrated and dried under vacuum to obtain $15 \mathrm{c}^{*} \mathrm{HCl}$ (ca. $0.08 \mathrm{~g}$, quantitative) as an offwhite solid. HRMS (ESI): $m / z[\mathrm{M}+\mathrm{H}]^{+}$calcd for $\mathrm{C}_{14} \mathrm{H}_{15} \mathrm{~N}_{4}$ : 239.12968; found: 239.12930. MS (ESI): $\mathrm{m} / z, 239.3$ for $[\mathrm{M}+$ $\mathrm{H}]^{+}$; 237.3 for $[\mathrm{M}-\mathrm{H}]^{-}, 273.0$ for $[\mathrm{M}+\mathrm{Cl}]^{-}$. ${ }^{1} \mathrm{H}$ NMR $(400$ $\left.\mathrm{MHz}, \mathrm{D}_{2} \mathrm{O}\right): \delta, 8.35(\mathrm{~s}, 1 \mathrm{H}), 7.28-7.19(\mathrm{~m}, 4 \mathrm{H}), 7.11-7.09$ $(\mathrm{m}, 2 \mathrm{H}), 3.09-3.05(\mathrm{~m}, 2 \mathrm{H}), 2.99-2.96(\mathrm{~m}, 2 \mathrm{H}) \mathrm{ppm} .{ }^{13} \mathrm{C}$ NMR $\left(100 \mathrm{MHz}, \mathrm{D}_{2} \mathrm{O}\right): \delta, 146.6,143.6,140.6,128.8,128.6$, $127.0,126.5,123.8,114.7,34.6,29.3 \mathrm{ppm}$.

\section{ASSOCIATED CONTENT}

\section{S Supporting Information}

The Supporting Information is available free of charge on the ACS Publications website at DOI: 10.1021/acsomega.7b01159.

Detailed experimental procedures and characterization data of all synthesized compounds; copies of ${ }^{1} \mathrm{H}$ and ${ }^{13} \mathrm{C}$ NMR spectra (PDF)

\section{AUTHOR INFORMATION}

\section{Corresponding Author}

*E-mail: mtanasov@mtu.edu.

ORCID

Łukasz J. Weseliński: 0000-0003-4516-2727

Marina Tanasova: 0000-0003-4771-9533

Notes

The authors declare no competing financial interest.

\section{ACKNOWLEDGMENTS}

This research was supported by Michigan Technological University (MTU, REF-SEED and Portage Health Foundation, M.T. Grant \#2015-025). The authors gratefully acknowledge MTU Chemical Advanced Resolution Methods (ChARM) Laboratory for HRMS analysis and Jerry Lutz for help with 2DNMR experiments.

\section{REFERENCES}

(1) Jordheim, L. P.; Durantel, D.; Zoulim, F.; Dumontet, C. Advances in the development of nucleoside and nucleotide analogues for cancer and viral diseases. Nat. Rev. Drug Discovery 2013, 12, 447464.

(2) Sharma, S.; Mehndiratta, S.; Kumar, S.; Singh, J.; Bedi, P. M. S.; Nepali, K. Purine analogues as kinase inhibitors: A review. Recent Pat. Anti-Cancer Drug Discovery 2015, 10, 308-341.

(3) Šála, M.; Kogler, M.; Plackova, P.; Mejdrova, I.; Hrebabecky, H.; Prochazkova, E.; Strunin, D.; Lee, G.; Birkus, G.; Weber, J.; Mertlikova-Kaiserova, H.; Nencka, R. Purine analogs as phosphatidylinositol 4-kinase III beta inhibitors. Bioorg. Med. Chem. Lett. 2016, 26, 2706-2712.

(4) Shaughnessy, K. H. Palladium-catalyzed modification of unprotected nucleosides, nucleotides, and oligonucleotides. Molecules 2015, 20, 9419-9454.
(5) Yang, Y. X.; Cohn, P.; Dyer, A. L.; Eom, S. H.; Reynolds, J. R.; Castellano, R. K.; Xue, J. G. Blue-violet electroluminescence from a highly fluorescent purine. Chem. Mater. 2010, 22, 3580-3582.

(6) Venkatesh, V.; Shukla, A.; Sivakumar, S.; Verma, S. Purinestabilized green fluorescent gold nanoclusters for cell nuclei imaging applications. ACS Appl. Mater. Interfaces 2014, 6, 2185-2191.

(7) Yang, Y. X.; Cohn, P.; Eom, S. H.; Abboud, K. A.; Castellano, R. K.; Xue, J. G. Ultraviolet-violet electroluminescence from highly fluorescent purines. J. Mater. Chem. C 2013, 1, 2867-2874.

(8) Aso, T.; Saito, K.; Suzuki, A.; Saito, Y. Synthesis and photophysical properties of pyrene-labeled 3-deaza-2'-deoxyadenosines comprising a non-pi-conjugated linker: Fluorescence quenchingbased oligodeoxynucleotide probes for thymine identification. Org. Biomol. Chem. 2015, 13, 10540-10547.

(9) Suzuki, A.; Yanaba, T.; Saito, I.; Saito, Y. Molecular design of an environmentally sensitive fluorescent nucleoside, 3-deaza-2'-deoxyadenosine derivative: Distinguishing thymine by probing the DNA minor groove. ChemBioChem 2014, 15, 1638-1643.

(10) Herdewijn, P. Modified Nucleosides: In Biochemistry, Biotechnology and Medicine; Wiley-VCH Verlag GmbH \& Co. KGaA: Weinheim, Germany, 2008.

(11) Kornberg, R. The molecular basis of eukaryotic transcription (Nobel lecture). Angew. Chem., Int. Ed. 2007, 46, 6956-6965.

(12) Irani, R. J.; SantaLucia, J. The synthesis of anti-fixed 3-methyl-3deaza-2'-deoxyadenosine and other $3 \mathrm{H}$-imidazo[4,5-c]pyridine analogs. Nucleosides, Nucleotides Nucleic Acids 2002, 21, 737-751.

(13) Salandria, K. J.; Arico, J. W.; Calhoun, A. K.; McLaughlin, L. W. Stability of DNA containing a structural water mimic in an A-T rich sequence. J. Am. Chem. Soc. 2011, 133, 1766-1768.

(14) Pal, A.; Salandria, K. J.; Arico, J. W.; Schlegel, M. K.; McLaughlin, L. W. 2,3-Dicyclohexylsuccinimide as a directing/ protecting group for the regioselective glycosylation or alkylation of purines. Chem. Commun. 2013, 49, 2936-2938.

(15) Crey-Desbiolles, C.; Kotera, M. Synthesis of 3-deaza-3-nitro-2' deoxyadenosine. Bioorg. Med. Chem. 2006, 14, 1935-1941.

(16) Minakawa, N.; Kawano, Y.; Murata, S.; Inoue, N.; Matsuda, A. Oligodeoxynucleotides containing 3-bromo-3-deazaadenine and 7bromo-7-deazaadenine 2'-deoxynucleosides as chemical probes to investigate DNA-protein interactions. ChemBioChem 2008, 9, 464470.

(17) Liu, C.; Chen, Q.; Gorden, J. D.; Schneller, S. W. 2-and 3Fluoro-3-deazaneplanocins, 2-fluoro-3-deazaaristeromycins, and 3methyl-3-deazaneplanocin: Synthesis and antiviral properties. Bioorg. Med. Chem. 2015, 23, 5496-5501.

(18) Saito-Tarashima, N.; Kira, H.; Wada, T.; Miki, K.; Ide, S.; Yamazaki, N.; Matsuda, A.; Minakawa, N. Groove modification of siRNA duplexes to elucidate siRNA-protein interactions using 7bromo-7-deazaadenosine and 3-bromo-3-deazaadenosine as chemical probes. Org. Biomol. Chem. 2016, 14, 11096-11105.

(19) Liu, C.; Chen, Q.; Schneller, S. W. Enantiomeric 3-deaza-1',6'isoneplanocin and its 3-bromo analogue: Synthesis by the Ullmann reaction and their antiviral properties. Bioorg. Med. Chem. Lett. 2016, 26, 928-930.

(20) Liu, C.; Chen, Q.; Yang, M.; Schneller, S. W. C-3 halo and 3methyl substituted 5'-nor-3-deazaaristeromycins: Synthesis and antiviral properties. Bioorg. Med. Chem. 2013, 21, 359-364.

(21) Liu, C.; Chen, Q.; Schneller, S. W. 3-Bromo-3-deazaneplanocin and 3-bromo-3-deazaaristeromycin: Synthesis and antiviral activity. Bioorg. Med. Chem. Lett. 2012, 22, 5182-5184.

(22) Minakawa, N.; Kojima, N.; Matsuda, A. Nucleosides and nucleotides. 184. Synthesis and conformational investigation of antifixed 3-deaza-3-halopurine ribonucleosides. J. Org. Chem. 1999, 64, $7158-7172$

(23) Malvezzi, S.; Angelov, T.; Sturla, S. J. Minor groove 3-deazaadenosine analogues: Synthesis and bypass in translesion DNA synthesis. Chem. - Eur. J. 2017, 23, 1101-1109.

(24) Hocek, M.; Dvorakova, H. An efficient synthesis of 2-substituted 6-methylpurine bases and nucleosides by $\mathrm{Fe}$ - or Pd-catalyzed cross- 
coupling reactions of 2,6-dichloropurines. J. Org. Chem. 2003, 68, 5773-5776.

(25) Hocek, M.; Silhar, P.; Shih, I. H.; Mabery, E.; Mackman, R. Cytostatic and antiviral 6-arylpurine ribonucleosides. Part 7: Synthesis and evaluation of 6-substituted purine L-ribonucleosides. Bioorg. Med. Chem. Lett. 2006, 16, 5290-5293.

(26) Nauš, P.; Kuchar, M.; Hocek, M. Cytostatic and antiviral 6arylpurine ribonucleosides IX. Synthesis and evaluation of 6substituted 3-deazapurine ribonucleosides. Collect. Czech. Chem. Commun. 2008, 73, 665-678.

(27) Wang, D. C.; Niu, H. Y.; Qu, G. R.; Liang, L.; Wei, X. J.; Zhang, Y.; Guo, H. M. Nickel-catalyzed Negishi cross-couplings of 6chloropurines with organozinc halides at room temperature. Org. Biomol. Chem. 2011, 9, 7663-7666.

(28) Čapek, P.; Vrábel, M.; Hasník, Z.; Pohl, R.; Hocek, M. Aqueousphase Suzuki-Miyaura cross-coupling reactions of free halopurine bases. Synthesis 2006, 3515-3526.

(29) Suzuki, A. Cross-coupling reactions of organoboranes: an easy way to construct C-C bonds (Nobel Lecture). Angew. Chem., Int. Ed. 2011, 50, 6722-6737.

(30) Netherton, M. R.; Fu, G. C. Air-stable trialkylphosphonium salts: Simple, practical, and versatile replacements for air-sensitive trialkylphosphines. Applications in stoichiometric and catalytic processes. Org. Lett. 2001, 3, 4295-4298.

(31) Kudo, N.; Perseghini, M.; Fu, G. C. A versatile method for Suzuki cross-coupling reactions of nitrogen heterocycles. Angew. Chem., Int. Ed. 2006, 45, 1282-1284.

(32) Luebke, R.; Belmabkhout, Y.; Weselinski, L. J.; Cairns, A. J.; Alkordi, M.; Norton, G.; Wojtas, L.; Adil, K.; Eddaoudi, M. Versatile rare earth hexanuclear clusters for the design and synthesis of highlyconnected ftw-MOFs. Chem. Sci. 2015, 6, 4095-4102.

(33) Magano, J.; Monfette, S. Development of an air-stable, broadly applicable nickel source for nickel-catalyzed cross-coupling. ACS Catal. 2015, 5, 3120-3123.

(34) Krenitsky, T. A.; Rideout, J. L.; Chao, E. Y.; Koszalka, G. W.; Gurney, F.; Crouch, R. C.; Cohn, N. K.; Wolberg, G.; Vinegar, R. Imidazo[4,5-c]pyridines (3-deazapurines) and their nucleosides as immunosuppressive and antiinflammatory agents. J. Med. Chem. 1986, 29, 138-143.

(35) Su, M.; Hoshiya, N.; Buchwald, S. L. Palladium-catalyzed amination of unprotected five-membered heterocyclic bromides. Org. Lett. 2014, 16, 832-835.

(36) Lougiakis, N.; Gavriil, E. S.; Kairis, M.; Sioupouli, G.; Lambrinidis, G.; Benaki, D.; Krypotou, E.; Mikros, E.; Marakos, P.; Pouli, N.; Diallinas, G. Design and synthesis of purine analogues as highly specific ligands for FcyB, a ubiquitous fungal nucleobase transporter. Bioorg. Med. Chem. 2016, 24, 5941-5952.

(37) Chida, N.; Suzuki, T.; Tanaka, S.; Yamada, I. Pd-Catalyzed coupling reaction of glycosylamines with 6-chloropurines: Synthesis of 6-(beta-D-mannopyranosylamino)-9H-purine and its beta- $\mathrm{D}$-gluco isomer, N-glycoside models for spicamycin and septacidin. Tetrahedron Lett. 1999, 40, 2573-2576.

(38) De Riccardis, F.; Johnson, F. Chemical synthesis of cross-linked purine nucleosides. Org. Lett. 2000, 2, 293-295.

(39) Lakshman, M. K. Palladium-catalyzed C-N and C-C crosscouplings as versatile, new avenues for modifications of purine 2 deoxynucleosides. J. Organomet. Chem. 2002, 653, 234-251.

(40) Surry, D. S.; Buchwald, S. L. Dialkylbiaryl phosphines in Pdcatalyzed amination: A user's guide. Chem. Sci. 2011, 2, 27-50.

(41) Maiti, D.; Fors, B. P.; Henderson, J. L.; Nakamura, Y.; Buchwald, S. L. Palladium-catalyzed coupling of functionalized primary and secondary amines with aryl and heteroaryl halides: Two ligands suffice in most cases. Chem. Sci. 2011, 2, 57-68.

(42) Tichý, M.; Pohl, R.; Xu, H. Y.; Chen, Y. L.; Yokokawa, F.; Shi, P. Y.; Hocek, M. Synthesis and antiviral activity of 4,6-disubstituted pyrimido[4,5-b]indole ribonucleosides. Bioorg. Med. Chem. 2012, 20, 6123-6133.
(43) Borchardt, A.; Davis, R.; Noble, S. A. Heterocyclic inhibitors of Histamine Receptors for the Treatment of Disease. World Pat. Appl. WO2011112766 A3, 2011.

(44) Molander, G. A.; Yun, C. S. Cross-coupling reactions of primary alkylboronic acids with aryl triflates and aryl halides. Tetrahedron 2002, $58,1465-1470$.

(45) Niu, C. S.; Li, J.; Doyle, T. W.; Chen, S. H. Synthesis of 3aminopyridine-2-carboxaldehyde thiosemicarbazone (3-AP). Tetrahedron 1998, 54, 6311-6318.

(46) Hirota, K.; Kitade, Y.; Kanbe, Y.; Maki, Y. Convenient method for the synthesis of $\mathrm{C}$-alkylated purine nucleosides: Palladiumcatalyzed cross-coupling reaction of halogenopurine nucleosides with trialkylaluminums. J. Org. Chem. 1992, 57, 5268-5270.

(47) King, A. O.; Okukado, N.; Negishi, E. I. Highly general stereo-, regio-, and chemo-selective synthesis of terminal and internal conjugated enynes by $\mathrm{Pd}$-catalysed reaction of alkynylzinc reagents with alkenyl halides. J. Chem. Soc., Chem. Commun. 1977, 683-684.

(48) Everson, D. A.; Jones, B. A.; Weix, D. J. Replacing conventional carbon nucleophiles with electrophiles: Nickel-catalyzed reductive alkylation of aryl bromides and chlorides. J. Am. Chem. Soc. 2012, 134, 6146-6159.

(49) Sanderson, J. N.; Dominey, A. P.; Percy, J. M. Iron-catalyzed isopropylation of electron-deficient aryl and heteroaryl chlorides. Adv. Synth. Catal. 2017, 359, 1007-1017.

(50) McCann, L. C.; Organ, M. G. On the remarkably different role of salt in the cross-coupling of arylzincs from that seen with alkylzincs. Angew. Chem., Int. Ed. 2014, 53, 4386-4389.

(51) Hunter, H. N.; Hadei, N.; Blagojevic, V.; Patschinski, P.; Achonduh, G. T.; Avola, S.; Bohme, D. K.; Organ, M. G. Identification of a higher-order organozincate intermediate involved in Negishi cross-coupling reactions by mass spectrometry and NMR spectroscopy. Chem. - Eur. J. 2011, 17, 7845-7851.

(52) Seiple, I. B.; Su, S.; Young, I. S.; Nakamura, A.; Yamaguchi, J.; Jorgensen, L.; Rodriguez, R. A.; O’Malley, D. P.; Gaich, T.; Kock, M.; Baran, P. S. Enantioselective total syntheses of (-)-palau'amine, (-)-axinellamines, and (-)-massadines. J. Am. Chem. Soc. 2011, 133, $14710-14726$.

(53) Arico, J. W.; Calhoun, A. K.; Salandria, K. J.; McLaughlin, L. W. Tetramethylsuccinimide as a directing/protecting group in purine glycosylations. Org. Lett. 2010, 12, 120-122.

(54) Casimiro-Garcia, A.; Heemstra, R. J.; Bigge, C. F.; Chen, J.; Ciske, F. A.; Davis, J. A.; Ellis, T.; Esmaeil, N.; Flynn, D.; Han, S.; Jalaie, M.; Ohren, J. F.; Powell, N. A. Design, synthesis, and evaluation of imidazo[4,5-c]pyridin-4-one derivatives with dual activity at angiotensin II type 1 receptor and peroxisome proliferator-activated receptor-gamma. Bioorg. Med. Chem. Lett. 2013, 23, 767-772.

(55) Bae, S.; Lakshman, M. K. Synthetic utility of an isolable nucleoside phosphonium salt. Org. Lett. 2008, 10, 2203-2206.

(56) Kodra, J. T.; Benner, S. A. Synthesis of an N-alkyl derivative of 2'-deoxyisoguanosine. Synlett 1997, 939-940.

(57) Gottlieb, H. E.; Kotlyar, V.; Nudelman, A. NMR chemical shifts of common laboratory solvents as trace impurities. J. Org. Chem. 1997, $62,7512-7515$.

(58) Luo, X.; Zhang, H.; Duan, H.; Liu, O.; Zhu, W.; Zhang, T.; Lei, A. Superior effect of a pi-acceptor ligand (Phosphine-electron-deficient olefin ligand) in the Negishi coupling involving alkylzinc reagents. Org. Lett. 2007, 9, 4571-4574.

(59) Whitesides, G. M.; Hackett, M.; Brainard, R. L.; Lavalleye, J. P. P. M.; Sowinski, A. F.; Izumi, A. N.; Moore, S. S.; Brown, D. W.; Staudt, E. M. Suppression of unwanted heterogeneous platinum(0)catalyzed reactions by poisoning with mercury $(0)$ in systems involving competing homogeneous reactions of soluble organoplatinum compounds: Thermal-decomposition of bis(triethylphosphine)3,3,4,4-tetramethylplatinacyclopentane. Organometallics 1985, 4, $1819-1830$.

(60) Gahlon, H. L.; Sturla, S. J. Hydrogen bonding or stacking interactions in differentiating duplex stability in oligonucleotides containing synthetic nucleoside probes for alkylated DNA. Chem. Eur. J. 2013, 19, 11062-11067. 